\title{
IDŐJÁRÁS
}

Quarterly Journal of the Hungarian Meteorological Service

Vol. 125, No. 1, January-March, 2021, pp. 1-37

\section{A case study of a derecho storm in dry, high-shear environment}

\section{Zoltán Sipos ${ }^{1}$, André Simon ${ }^{2} *$, Kálmán Csirmaz ${ }^{2}$, Tünde Lemler ${ }^{2}$, Robert-Daniel Manta ${ }^{1}$, and Zsófia Kocsis ${ }^{2}$}

\author{
${ }^{1}$ National Meteorological Administration \\ Sos. Bucureşti-Ploieşti nr. 97, Sector 1, \\ 013686 Bucureşti, Romania \\ ${ }^{2}$ Hungarian Meteorological Service \\ Kitaibel Pál u. 1, 1024 Budapest, Hungary
}

*Corresponding author E-mail: simon.a@met.hu

(Manuscript received in final form January 29, 2020)

\begin{abstract}
The present study examines the origin and environmental conditions of the severe convective windstorm on September 17, 2017, which affected several countries in the central and southeastern Europe, above all Serbia and Romania. The large area of the damage swath (at least $500 \mathrm{~km}$ long) and high wind gusts (up to $40 \mathrm{~m} / \mathrm{s}$ ) would classify this event as a derecho or at least as a storm very similar to derechos (with respect to newer definition proposals). Small-scale bow echoes were found in areas with highest reported wind gusts, and some thunderstorms within the storm-producing convective system were probably supercells. The existence of high wind shear and storm rotation could be also related to the significant rightward deflection of the system with respect to the mean wind and propagation of other thunderstorms and systems observed on that day. In contrary to many other known derecho events, this storm propagated toward a very dry airmass exhibiting only low or moderate convective available potential energy (CAPE) values. This is shown by soundings, ECMWF model outputs, and vertical profiles from the IASI L2 satellite sounder. Several convective parameters (e.g. CAPE, downdraft CAPE, derecho composite parameter, 0-3-km relative humidity, 0-6-km shear) were evaluated and compared with proximity soundings of other described European derechos or with the available climatology. The possibility of a balance between the cold pool-generated horizontal vorticity and the environmental shear is also discussed. It is concluded that identification of low-level humidity sources (with aid of storm-relative wind vectors or streamlines) can be important in forecasting of thunderstorm systems moving toward an airmass, which is seemingly too dry for development and maintenance of deep convection. It is also shown that due to low CAPE values, some composite parameters would not indicate favourable conditions for a long-lived convective system. The lack of radiosonde observations can be partially supplemented by data from the IASI L2 sounder, which profiles can be largely different from model forecasts, showing much drier air in the mid-
\end{abstract}


and upper troposphere in this case. It is concluded that due to the absence of strong synoptic forcing and larger pressure gradient at surface, convective processes played major role in the windstorm development. The presence of high temperature lapse rates at low- and midlevels, high wind shear and unusually dry pre-storm airmass could be considered as the most important signatures related to the storm severity.

Key-words: derecho, high-shear, dry air, low-to-moderate CAPE, storm-relative wind, IASI L2 profiles, bow echo, WER echo

\section{Introduction}

On September 17, 2017, a mesoscale convective system (MCS) caused severe windstorm over Serbia and Romania. The highest measured gust reached $40 \mathrm{~m} / \mathrm{s}$, wind gusts exceeding $26 \mathrm{~m} / \mathrm{s}$ (and damages by wind) occurred in an approximately $500 \mathrm{~km}$ long and at least $100 \mathrm{~km}$ wide swath over the northern part of Serbia and western part of Romania (Fig. 1). This would classify the event as a derecho (Johns and Hirt, 1987, hereafter JH87) or at least as a derecho-like storm according the newer definition proposal (Corfidi et al., 2016). In JH87 the condition for the length of the major axis of the derecho was $400 \mathrm{~km}$, whereas in Corfidi et al., 2016 it was increased to $650 \mathrm{~km}$. The JH87 paper described two kinds of derecho storms - progressive and serial. In the presented case we could see one compact pattern of high wind gusts and accompanied damages, which was extending nearly in the direction of the mean flow, which is typical for progressive derecho types. Although severe thunderstorms are common in Serbia and Romania (Lemon et al., 2003, Antonescu and Burcea, 2010, Pavlović-Berdon et al., 2013, Antonescu and Bell, 2015, Rabrenović, 2015), storms causing such widespread windstorms are relatively rare in this area and are less documented in scientific papers. We are aware of only few publications dealing with large convective systems in southeastern Europe, though some storms were recently studied also with aid of numerical models (Lompar et al., 2017) and there were also attempts for climatology of convective gusts (Rabrenović and Gatzen, 2017). One of the well documented events in the neighboring region was the derecho storm of July 20, 2011 (Gospodinov et al., 2015), which hit Bulgaria and the southern part of Romania. Other known and published derecho events refer rather to the area of Central Europe, Spain, or Finland (Gatzen, 2004; Gatzen and Púčik, 2011; Púčik et al., 2011; Simon et al., 2011; Celińsky-Mysław and Matuszko, 2014; López, 2007; Punkka et al., 2006). Because of relatively small number of known cases, little is known about the climatology of derechos and similar windstorms in Europe, except of some regions as Germany (Gatzen et al., 2015). More information about the environment and macrosynoptic conditions for long-lived convective windstorms is available from the USA (Evans and Doswell, 2001, hereafter ED01, Coniglio et al., 2004). ED01 provided analysis of 67 derechos upon 113 proximity soundings. They identified cases with "weak" and "strong" 
synoptic forcing. The latter ones were associated with advancing mid-level trough accompanied by well-expressed surface cyclone. They found that derechos can develop and exist in many different instability and wind shear conditions. Although, early numerical simulations (Rotunno et al., 1988, hereafter RKW88, Weismann, 1992) of long-lived mesoscale convective systems indicated that such storms could be maintained rather when high wind shear is present at low- and middle tropospheric levels, derecho cases occur also in moderate wind shear environments. Still, wind shear and transport of momentum from higher levels in the cold pool area can be important for the propagation of the system and for the speed of wind gusts (Mahoney et al., 2009). Derecho storms were also reported in situations with very low or no convective available potential energy (CAPE) in neighboring soundings, although this is typical rather for strong synoptic forcing (ED01, Gatzen et al., 2011). High relative humidity (above 70\%) is typically found in derecho environments at low levels, while replaced by drier air at mid-levels (Coniglio et al., 2004). Studies of MCS storms (Cohen et al., 2007) also showed steeper lapse rates $(6-8 \mathrm{~K} / \mathrm{km})$ at mid-levels compared to weak MCS events. In the synoptic-scale flow, $250 \mathrm{hPa}$ flow divergence is often found in the proximity of these storms, and in most of the cases a well-defined $500 \mathrm{hPa}$ upstream trough is found, though, ridge or zonal flows were also observed (Coniglio et al., 2004). Severe, long-lasting convective storms are related to quasi-linear convective systems, often exhibiting bow echoes (Fujita, 1978) or mesovortices (Weisman and Trapp, 2003), which can be detected on the radar imagery. The presence of these features is also expected in the newer derecho definition (Corfidi et al., 2016). Supercell storms (Browning, 1962) occasionally also cause long swathes of severe weather along their path, however, the size of the storm-impact territory and width of the swath is inferior compared to derecho storms. Supercells can be embedded in long-lived mesoscale systems (Corfidi, 2003, Bunkers et al., 2006) or can be attached to developing convective systems (Taszarek et al., 2019). On radar images, the presence of supercell mesocyclone is usually identified upon radial-doppler wind measurements as a mesoscale vortex signature (MVS). An indirect evidence of the supercell-related flow is the presence of persistent weak echo regions (WER) or bounded weak echo regions (BWER) in the field of radar reflectivity (Moller et al., 1994). It can be expected that embedded supercells cause a local intensification of the windstorm or even deflection of the propagation of the whole system (Corfidi, 2003). Though, the rate of this influence is ambiguous, since it is often observed that the presence of low-level jet causes deviation of the MCS propagation with respect to the mean flow, which is typically rightward (Corfidi et al., 1996, Corfidi, 2003). Climatological studies suggested that mostly the deviation between the MCS motion and deep-layer shear vector remains within 30 degrees, even in case of derechos (Cohen et al., 2007). 


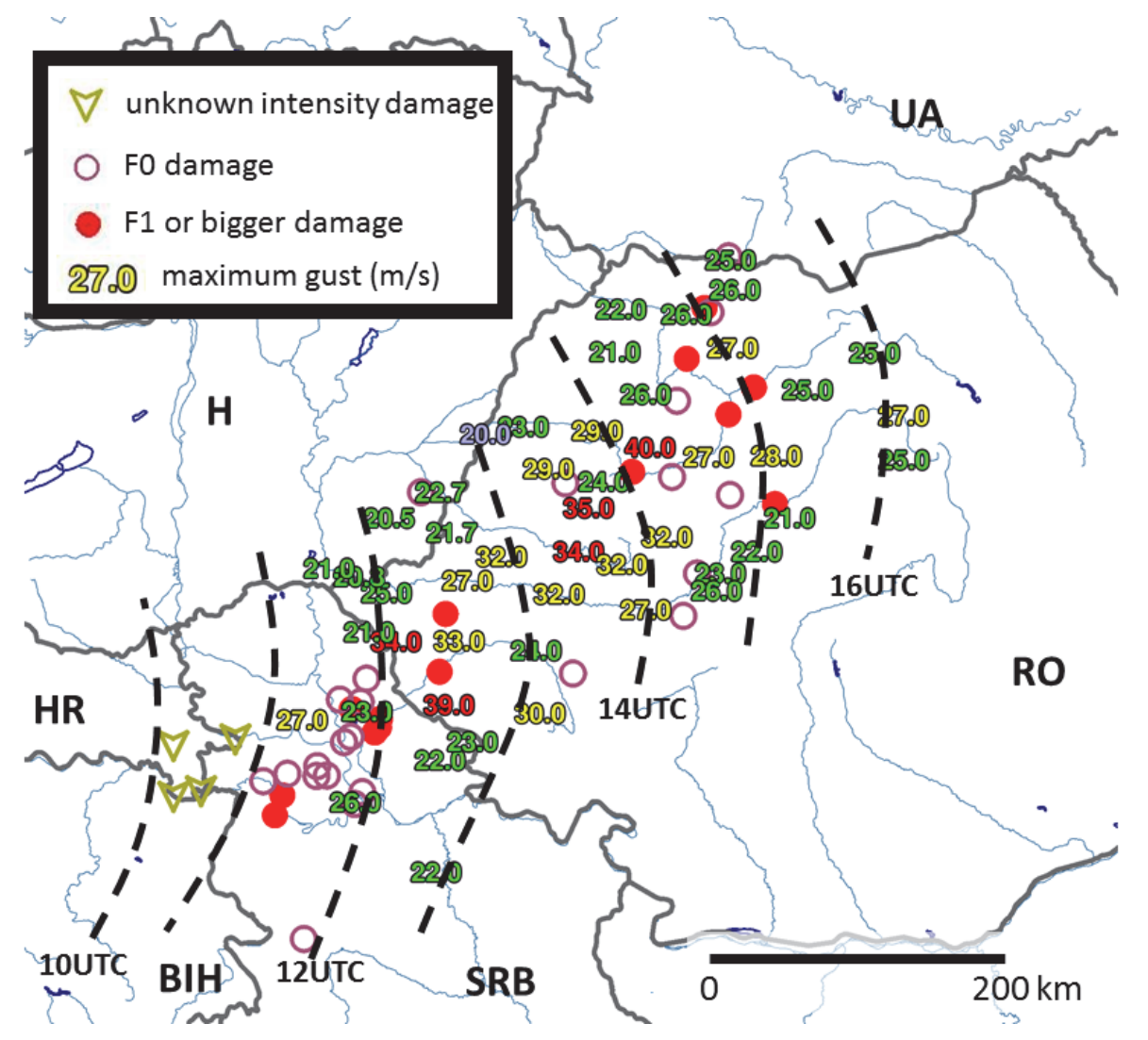

Fig. 1. Maximum wind gusts measured during the September 17, 2017 windstorm by surface weather stations (number, $\mathrm{m} / \mathrm{s}$ ) and damage reports (F0 - empty circles, F1 - full circles, unknown - wind squall symbols). Depicted are only gusts exceeding $20 \mathrm{~m} / \mathrm{s}$. Positions of the leading edge of the convective system are shown by dashed lines. Letters BIH, H, HR, RO, SRB, UA denote Bosnia and Hercegovina, Hungary, Croatia, Romania, Serbia, Ukraine.

The above-mentioned typical features of long-lived convective windstorms were considered also during the study of the evolution of the September 17, 2017 storm and of its environment. We focused primarily on the pre-storm environment as derived from available soundings, numerical model analyses, and forecasts. Section 2 describes available sources of data, tools, and parameters chosen for the study. Section 3 gives an overview of the synopticscale situation and main characteristics of the storm environment acquired from soundings. Section 4 provides an insight to the structure and evolution of the convective system using radar and satellite imagery. Section 5 summarizes the known impact of the storm, above all in Romania. Section 6 shows the most important characteristics of the pre-storm environment, as derived from numerical weather prediction (NWP) data and compares them with environments of other known derecho events or with available climatology. The possibility of an equilibrium between the cold pool-generated vorticity and prestorm wind shear is also discussed. Most important findings are summarized in Section 7. 


\section{Methodology}

The present study was done using information from several types of observations (aerological, radar, satellite, and surface measurements) and outputs (analyses and forecasts) of the ECMWF numerical model. At the Hungarian Meteorological Service (OMSZ), an operational, mosaic radar imagery of Hungarian, Croatian, and Slovak radars was used throughout the study (depicted in Fig. 2). This imagery enabled us to follow the development of the convective system along large part of its track. However, for cells evolving over Romania (which were situated rather at the edge of the above-mentioned mosaic imagery), we also examined available products of Romanian radars (Table 1). Differences between the respective radar imageries were mostly quantitative (e.g., higher column maximum radar reflectivity measured by Romanian radars in case of some intense thunderstorms). These could be caused by different technical specifications and scanning strategies of the radars, screening effects, etc.

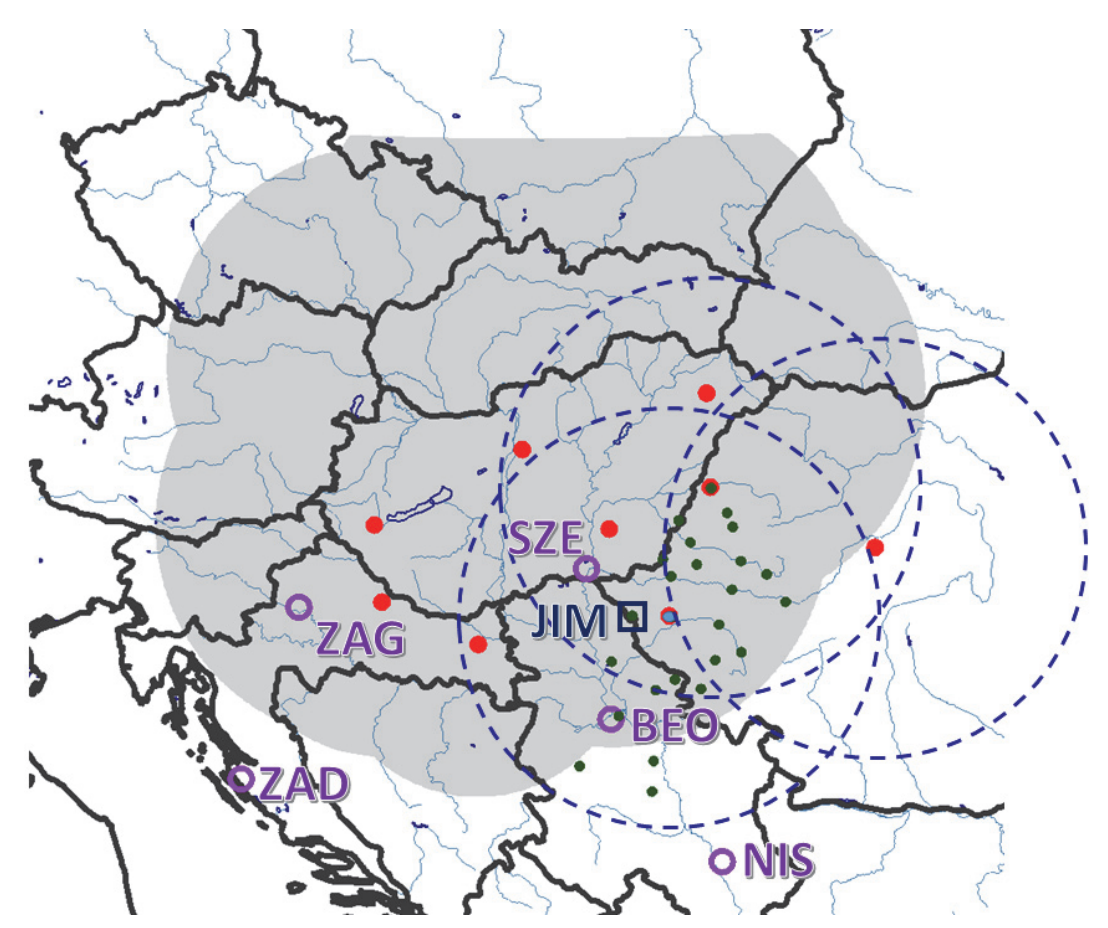

Fig. 2. Positions of radars (full circles) and area of coverage of the mosaic radar imagery of Hungarian, Croatian, and Slovak radars used in the study (shaded). The range of the Romanian radars in the eastern and central parts of the country is indicated by dashed circles. Empty circles show the positions of soundings on September17, 2017, at 00:00 and 12:00 UTC. Letters ZAD, ZAG, SZE, BEO, NIS denote Zadar, Zagreb, Szeged, Beograd, Nis. Letter JIM and rectangle shows the position of IASI L2 profile over Jimbolia (Romania). The smaller full dots show the positions of pseudo-soundings from the ECMWF used for the calculation of convective parameters and characterization of the pre-storm environment valid for September 17, 2017 at 12:00 UTC. 
Table 1. Overview of the radars and radar parameters used in the September 17, 2017 study.

\begin{tabular}{|c|c|c|c|c|c|c|c|c|c|}
\hline Station & Pogányvár & Budapest & Szentes & $\begin{array}{l}\text { Nyíregyháza- } \\
\text { Napkor }\end{array}$ & Bilogora & Osijek & Timisoara & Oradea & $\begin{array}{l}\text { Tarnaveni/ } \\
\text { Bobohalma }\end{array}$ \\
\hline Type & $\begin{array}{l}\text { DWSR- } \\
2501 C\end{array}$ & $\begin{array}{l}\text { DWSR- } \\
2500 \mathrm{C}\end{array}$ & $\begin{array}{l}\text { DWSR } \\
-5001 C\end{array}$ & $\begin{array}{l}\text { DWSR- } \\
2501 C\end{array}$ & $\begin{array}{l}\text { WSR- } \\
88 \mathrm{D}\end{array}$ & $\begin{array}{l}\text { DWSR } \\
74 \mathrm{~S}\end{array}$ & $\begin{array}{l}\text { WSR } \\
98 \mathrm{D}\end{array}$ & $\begin{array}{l}\text { WSR } \\
98 \mathrm{D}\end{array}$ & $\begin{array}{l}\text { WSR } \\
98 \mathrm{D}\end{array}$ \\
\hline Band & C-band & C-band & C-band & C-band & S-band & S-band & S-band & S-band & S-band \\
\hline $\begin{array}{l}\text { range } \\
(\mathrm{km})\end{array}$ & 240 & 240 & 240 & 240 & 240 & 240 & 230 & 230 & 230 \\
\hline $\begin{array}{l}\text { beam } \\
\text { width }\end{array}$ & $0.9^{\circ}$ & $0.94^{\circ}$ & $0.95^{\circ}$ & $0.96^{\circ}$ & $2.1^{\circ}$ & $2.1^{\circ}$ & $0.99^{\circ}$ & $0.99^{\circ}$ & $0.99^{\circ}$ \\
\hline
\end{tabular}

We used data of synoptic stations with hourly frequency (those, which were subject to international data exchange). We combined the radar and surface data also with the METEOSAT8 satellite outputs (mainly the $10.8 \mu \mathrm{m}$ infrared channel imagery). For the determination of the environment of various derecho cases (listed in Table 7), we used proximity soundings, which were launched in the area of the track of the storms, or in the nearby area, prior to the event. We preferably used soundings cited in the corresponding papers and studies (referenced in Table 7). For the September 17, 2017 windstorm we also used temperature and humidity profiles from IASI L2 satellite sounder data valid for 09:00 UTC. We preferably chose the same places for IASI diagnostics, where also surface observations and ECMWF model pseudosoundings were available. The surface IASI temperature and dew point values were replaced with observations of surface weather stations, knowing that the IASI errors are typically high at the surface (Roman et al., 2016).

The convective parameters were calculated by a program developed at OMSZ (Csirmaz, 2013) using standard approaches published in scientific literature (Rasmussen and Blanchard, 1998; Gilmore and Wicker, 1998; Bunkers et a1., 2000, etc.). The overview of these parameters is given in Table 2. We also calculated the derecho composite parameter or DCP (refer to website of the Storm Prediction Center, 2019 or to Lagerquist et al., 2017). This index yields:

$$
D C P=\left(\frac{D C A P E}{980}\right)\left(\frac{M U C A P E}{2000}\right)\left(\frac{0-6 k m \text { shear }}{10.288}\right)\left(\frac{0-6 k m \text { mean wind }}{8.23}\right),
$$

where the magnitudes of the 0-6-km above ground level (AGL) shear and mean wind are in $\mathrm{m} / \mathrm{s}$ and the constants in the denominator were modified correspondingly (knots were used in the original definition). The use of such composite parameters or indices is often criticized, because the way they are constructed is empirical, often without physical background (Doswell and Schultz, 2006; Bunkers, 2009). DCP was used here only as an indicator, whether the studied situation would fit the usual environment, in which derechos form. It is considered that favorable environments are characterized by DCP $>2$ (Lagerquist et al., 2017). 
Table 2. Overview of convective parameters and indices used in the presented study and operationally calculated at OMSZ.

\begin{tabular}{|c|c|c|c|}
\hline Parameter & Explanation & Unit & Remark \\
\hline $\begin{array}{l}\text { SBCAPE } \\
\text { (Emanuel, 1994) } \\
\text { (Doswell and } \\
\text { Rasmussen, 1994) }\end{array}$ & $\begin{array}{l}\text { Surface-based } \\
\text { convective available } \\
\text { potential energy }\end{array}$ & $\begin{array}{l}\mathrm{J} / \mathrm{kg}\left(\mathrm{m}^{2} \mathrm{~s}^{-}\right. \\
2)\end{array}$ & $\begin{array}{l}\text { Calculated with surface parcel, using } \\
\text { virtual temperature }\end{array}$ \\
\hline $\begin{array}{l}\text { SBCIN } \\
(\text { Colby, 1984) }\end{array}$ & $\begin{array}{l}\text { Surface-based } \\
\text { convective inhibition }\end{array}$ & $\mathrm{J} / \mathrm{kg}$ & Corresponding to SBCAPE calculation \\
\hline $\begin{array}{l}\text { MLCAPE } \\
\text { (e.g. Craven et al., } \\
\text { 2002, Davies;2004) }\end{array}$ & Mixed-layer CAPE & $\mathrm{J} / \mathrm{kg}$ & $\begin{array}{l}\text { Calculated with initial parcel with } \\
\text { averaged potential temperature and } \\
\text { mixing ratio in the lowest } 100 \mathrm{hPa}\end{array}$ \\
\hline $\begin{array}{l}\text { MUCAPE } \\
\text { (e.g. Thompson et al., } \\
\text { 2003) }\end{array}$ & Most unstable CAPE & $\mathrm{J} / \mathrm{kg}$ & $\begin{array}{l}\text { Calculated with most unstable initial } \\
\text { parcel between the surface and } 500 \\
\mathrm{hPa}\end{array}$ \\
\hline $\begin{array}{l}\text { MLCIN } \\
\text { (Colby, 1984; } \\
\text { Davies, 2004) }\end{array}$ & $\begin{array}{l}\text { Mixed-layer } \\
\text { convective inhibition }\end{array}$ & $\mathrm{J} / \mathrm{kg}$ & $\begin{array}{l}\text { Corresponding to MLCAPE } \\
\text { calculation }\end{array}$ \\
\hline $\begin{array}{l}\text { MUCIN } \\
\text { (Colby, 1984) }\end{array}$ & $\begin{array}{l}\text { Most unstable parcel } \\
\text { convective inhibition }\end{array}$ & $\mathrm{J} / \mathrm{kg}$ & $\begin{array}{l}\text { Corresponding to MUCAPE } \\
\text { calculation }\end{array}$ \\
\hline $\begin{array}{l}\text { DCAPE } \\
\text { (Gilmore and Wicker, } \\
\text { 1998) }\end{array}$ & $\begin{array}{l}\text { Downdraft } \\
\text { convective available } \\
\text { potential energy }\end{array}$ & $\mathrm{J} / \mathrm{kg}$ & $\begin{array}{l}\text { Calculated with virtual temperature and } \\
\text { initial parcel with lowest equivalent } \\
\text { potential temperature below } 500 \mathrm{hPa}\end{array}$ \\
\hline $\begin{array}{l}\text { BLI } \\
(\text { Galway, 1956; Fujita, } \\
\text { 1970) }\end{array}$ & Best Lifted Index & $\mathrm{K}$ & $\begin{array}{l}\text { Calculated with virtual temperature } \\
\text { and returning the most unstable value } \\
\text { for parcels initiated below } 1500 \mathrm{~m}\end{array}$ \\
\hline $\begin{array}{l}\text { Bunkers Storm Motion } \\
\text { Vector } \\
\text { (Bunkers et al., 2000) }\end{array}$ & $\begin{array}{l}\text { Storm motion vector } \\
\text { for supercells } \\
\text { propagating left- or } \\
\text { right to the mean } \\
\text { wind vector }\end{array}$ & $\mathrm{m} / \mathrm{s}$ & $\begin{array}{l}\text { Constructed with } 0-6 \mathrm{~km} \text { and } 0-500 \mathrm{~m} \\
\text { mean wind vectors }\end{array}$ \\
\hline $\begin{array}{l}\text { 0-3-km SREH } \\
\text { (Davies-Jones et al., } \\
\text { 1990) }\end{array}$ & $\begin{array}{l}\text { Storm-relative } \\
\text { environmental } \\
\text { helicity }\end{array}$ & $\mathrm{J} / \mathrm{kg}$ & $\begin{array}{l}\text { The Bunkers storm motion vector or } \\
\text { the actual storm motion vector was } \\
\text { used to calculate storm-relative wind }\end{array}$ \\
\hline 0-3-km RH & $\begin{array}{l}\text { Averaged relative } \\
\text { humidity for } 0-3-\mathrm{km} \\
\text { AGL layer }\end{array}$ & $\%$ & \\
\hline $\begin{array}{l}\text { MLMR } \\
\text { (Petersen et al., 1996; } \\
\text { University of } \\
\text { Wyoming, 2019) }\end{array}$ & $\begin{array}{l}\text { Mean mixed-layer } \\
\text { mixing ratio }\end{array}$ & $\mathrm{g} / \mathrm{kg}$ & $\begin{array}{l}\text { From the Wyoming website, } \\
\text { calculated as average mixing ratio in } \\
\text { the lowest } 500 \mathrm{~m}\end{array}$ \\
\hline $\begin{array}{l}\text { DCP } \\
\text { (Storm Prediction } \\
\text { Center, 2019, } \\
\text { Lagerquist et al., 2017) }\end{array}$ & $\begin{array}{l}\text { Derecho composite } \\
\text { parameter }\end{array}$ & $\begin{array}{l}\text { dimension } \\
\text { less }\end{array}$ & $\begin{array}{l}\text { The wind shear and wind speed } \\
\text { parameters recalculated from } \mathrm{kt} \text { to } \mathrm{m} / \mathrm{s}\end{array}$ \\
\hline
\end{tabular}


For the study of the synoptic situation and convective environment we used the September 17, 2017, 00:00 and 12:00 UTC analyses and forecasts of the global, hydrostatic ECMWF model (Persson, 2011). The model has nearly 0.1 degree $(9 \mathrm{~km})$ horizontal resolution in the area of the study and uses 137 vertical levels. The model uses parameterization of convection and convective gusts (Bechtold and Bidlot, 2009). Besides charts of meteorological parameters, we also used pseudotemps (pseudo-soundings) for 25 stations in the pre-storm environment on September 17, 2017, at 12:00 UTC (depicted in Fig. 2). The pseudotemp data were used to estimate the magnitude of SBCAPE and its sensitivity on the initial parcel properties (temperature, dew point, pressure).

Finally, for the visualization and calculation of certain features (e.g., streamlines) we used the system HAWK (Hungarian Advanced WorK Station) developed at OMSZ (Rajnai and Vörös, 2010).

\section{Synoptic situation and pre-storm soundings}

On September 17, 2017, at 12:00 UTC, there was a large but shallow area of low pressure over the central and southeastern parts of Europe, with a cold front over the Adriatic Sea, Croatia, Bosnia-Hercegovina, and Hungary, which was moving toward east (Fig. 3). A strong southerly flow of warm air and high temperature gradient could be found at $850 \mathrm{hPa}$ (Fig. 4) over Serbia and eastern part of Romania (the temperature changed by $11{ }^{\circ} \mathrm{C}$ on $400 \mathrm{~km}$ distance in northwestsoutheast direction). At the same time, there was a very strong, diffluent southwesterly flow at $500 \mathrm{hPa}$ (Fig. 5) and at levels above. This flow was around a large cyclone centered over the Benelux states and northern Germany, which slowly extended toward east.

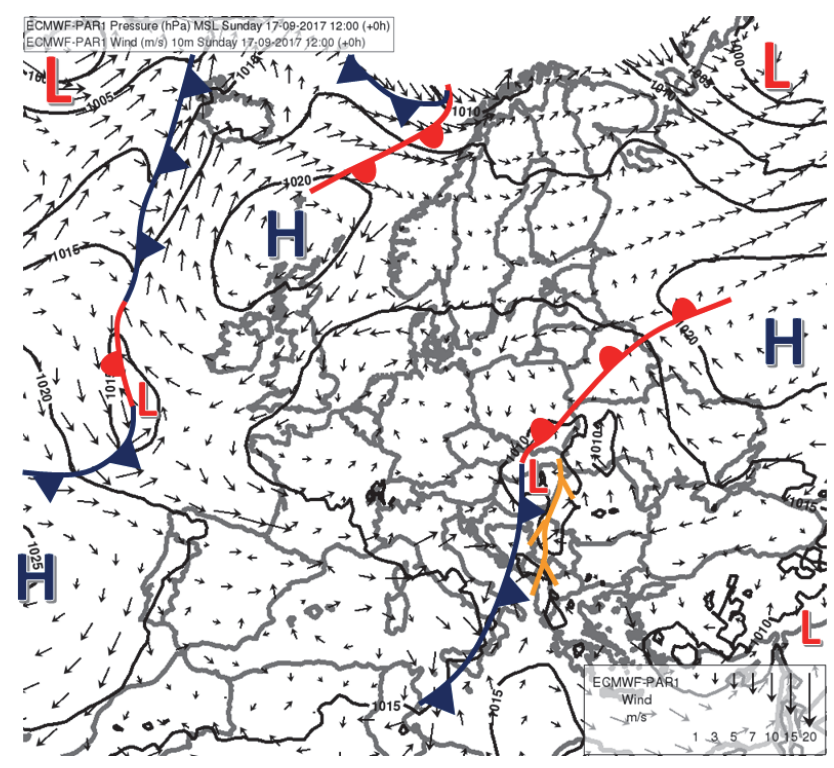

Fig. 3. Surface fronts and ECMWF analysis of mean sea-level pressure (solid lines, hPa) and $10 \mathrm{~m}$ wind (arrows, m/s) valid for September 17, 2017, 12:00 UTC. Tree-shaped symbols indicate convergence lines. Labels $\mathrm{L}$ and $\mathrm{H}$ are used for lows and highs. Wind vectors of 1,3 , $5,7,10,15,20 \mathrm{~m} / \mathrm{s}$ are depicted. 


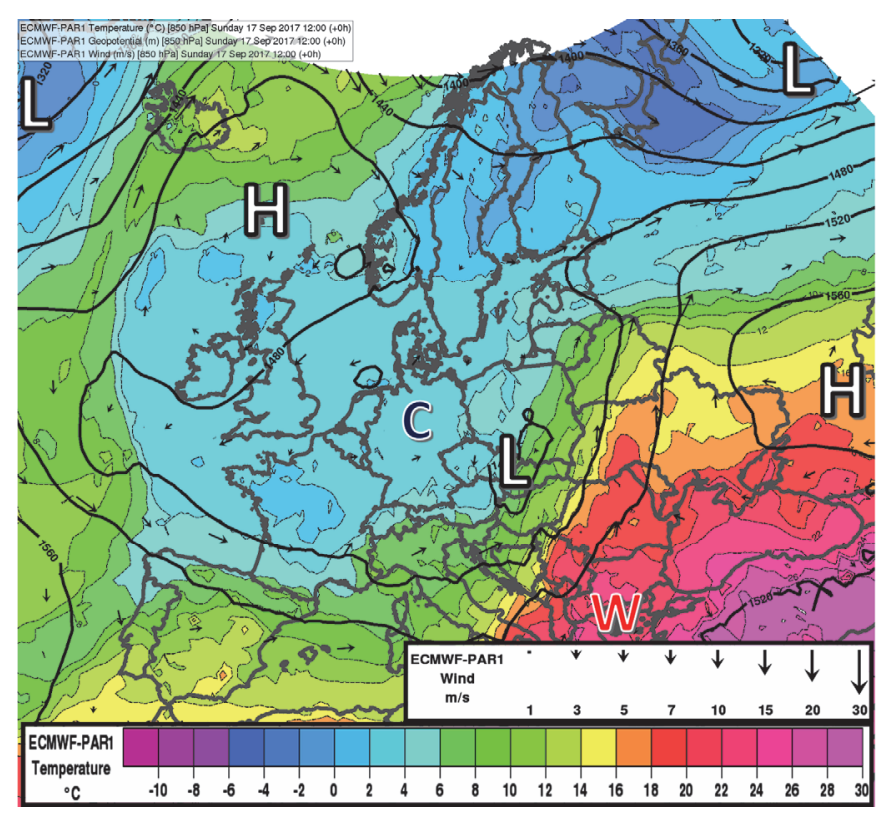

Fig. 4. ECMWF analysis of $850 \mathrm{hPa}$ geopotential (thick solid lines, by $40 \mathrm{gpm}$ ), temperature (shades and thin dashed lines, by $2^{\circ} \mathrm{C}$ ) and wind (arrows, m/s) valid for September 17, 2017, 12:00 UTC. Labels L and H are used for lows and highs, W and $\mathrm{C}$ for local temperature maxima and minima. The range of the temperature scale is from $-12{ }^{\circ} \mathrm{C}$ to $30^{\circ} \mathrm{C}$ by $2{ }^{\circ} \mathrm{C}$. Wind vectors of $1,3,5,7,10,15,20,30 \mathrm{~m} / \mathrm{s}$ are depicted.

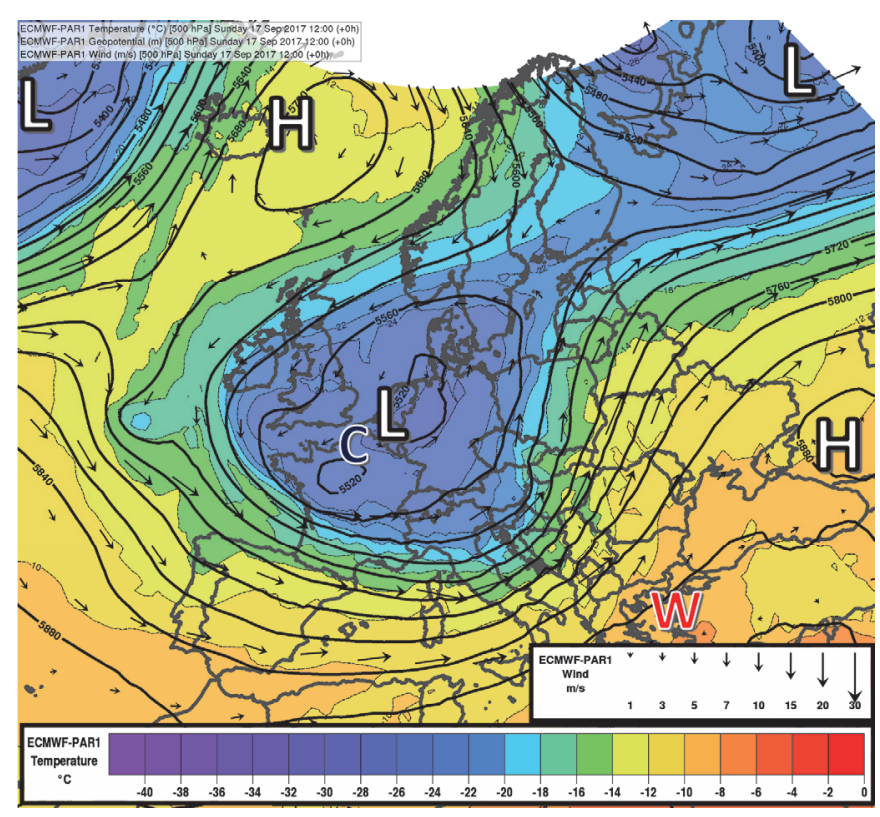

Fig. 5. As in Fig. 4., but for the $500 \mathrm{hPa}$ level. The range of the temperature scale is from $-42{ }^{\circ} \mathrm{C}$ to $0{ }^{\circ} \mathrm{C}$ by $2{ }^{\circ} \mathrm{C}$. Wind vectors of $1,3,5,7,10,15,20,30 \mathrm{~m} / \mathrm{s}$ are depicted.

The regional analysis of mean sea level pressure and synoptic observations at 12:00 UTC (Fig. 6) indicated that the storm-producing deep convection occurred at a pre-frontal convergence line extending across a meso-scale area of low pressure over the Serbian-Romanian border. Similarly to the $850 \mathrm{hPa}$ chart, the surface observations also showed high temperature contrasts. In the region, 
where the storm occurred, the daily maxima reached $30-34{ }^{\circ} \mathrm{C}$, which is unusual for the given period of year in this region. For example, at the Beograd Surčin station in Serbia, the 1952-1992 average maximum temperature in September was $24^{\circ} \mathrm{C}$ (World Climate, 2019). Northeast of the storm area, the $2 \mathrm{~m}$ temperature reached mostly $18-25{ }^{\circ} \mathrm{C}$.

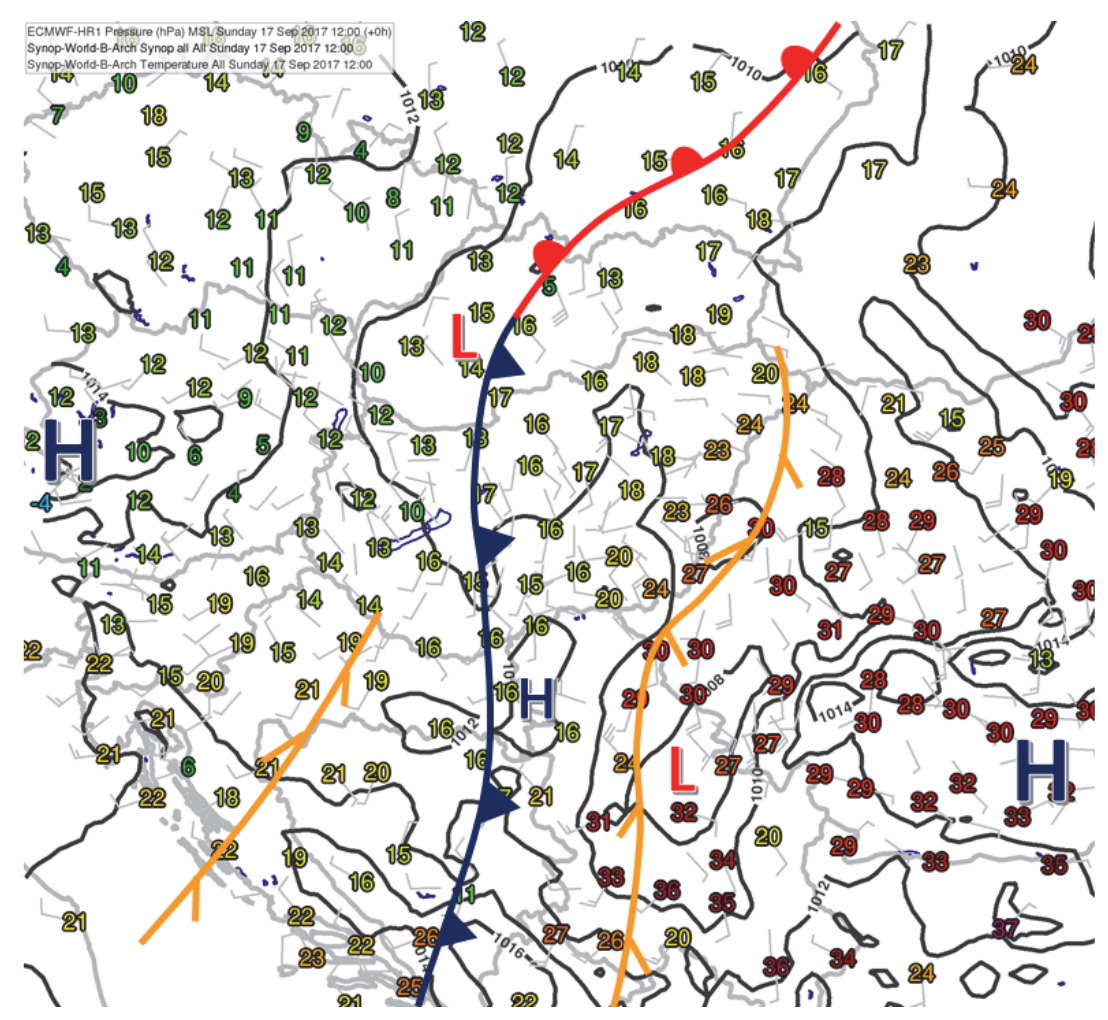

Fig. 6. Analysis of mean sea level pressure (lines, by $2 \mathrm{hPa}$ ), $10 \mathrm{~m}$ wind (barbs, $\mathrm{m} / \mathrm{s}$ ), and $2 \mathrm{~m}$ temperature (numbers, ${ }^{\circ} \mathrm{C}$ ) observed at respective synoptic stations and of surface fronts/convergence lines valid for September 17, 2017, 12:00 UTC. In the wind visualization (used also in other figures of this paper), half barbs represent $2.5 \mathrm{~m} / \mathrm{s}$, full barbs $5 \mathrm{~m} / \mathrm{s}$, and flags $25 \mathrm{~m} / \mathrm{s}$ wind speed values.

Derechos are sometimes distinguished according the synoptic situation as strong forcing (SF), weak forcing (WF), or hybrid events. The original definition (ED01) is rather vague, allowing quite wide interpretation. We believe that the case described here belonged to weak forcing events, because the system was not related to strong surface synoptic-scale cyclone and there was no rapid development or propagation of large-scale troughs and cyclones, in the upper-air fields. The strongly convective character of the event is also underlined by the fact that after the passage of the storm, the $10 \mathrm{~m}$ wind turned back to the original, southerly direction at many stations and weakened. This is rather typical for the summer convective storms, with prevailingly weak forcing. 
Just prior to the arrival of the storm, there was a sounding at Beograd Košutnjak (13275) referred to 12:00 UTC (Fig. 7a). It showed that the air was dry at low levels, with high (up to $20^{\circ} \mathrm{C}$ ) dewpoint depression and relatively high lifted condensation level (LCL), which was situated at around $700 \mathrm{hPa}$. The temperature lapse rate was high at low levels $(8.95 \mathrm{~K} / \mathrm{km}$ between 925 and 600 $\mathrm{hPa}$ ) but topped with an inversion at $600 \mathrm{hPa}$ height. Therefore, there was only very little CAPE (SBCAPE was $14 \mathrm{~J} / \mathrm{kg}$ ) concentrated just below the inversion. The lowest $0-6-\mathrm{km}$ wind shear was $39.5 \mathrm{~m} / \mathrm{s}$. Very high deep layer shear was found also in other soundings in the storm area (Table 3). However, the Beograd sounding was the only one, which was situated directly in the storm track and could be related to the pre-storm environment.

Table 3. Comparison of parameters derived from soundings in the area of the studied storm on September 17, 2017.

\begin{tabular}{|c|c|c|c|c|c|c|c|c|}
\hline Sounding & $\begin{array}{c}\text { Position/stage of } \\
\text { the storm } \\
\text { development }\end{array}$ & $\begin{array}{c}\text { MUCAPE } \\
\text { (MUCIN) } \\
(\mathbf{J} / \mathbf{k g}) \\
\end{array}$ & $\begin{array}{c}\text { MLCAPE } \\
\text { (MLCIN) } \\
(\mathrm{J} / \mathrm{kg}) \\
\end{array}$ & $\begin{array}{c}\text { 0-6-km } \\
\text { shear } \\
(\mathrm{m} / \mathrm{s}) \\
\end{array}$ & $\begin{array}{c}\text { DCAPE } \\
(\mathrm{J} / \mathbf{k g})\end{array}$ & $\begin{array}{c}\text { MLMR } \\
(\mathrm{g} / \mathrm{kg})\end{array}$ & $\begin{array}{c}\text { 0-3-km } \\
\text { RH (\%) }\end{array}$ & DCP \\
\hline $\begin{array}{l}\text { Beograd } \\
(13275) \\
12 \text { UTC }\end{array}$ & $\begin{array}{l}\text { forward flank of } \\
\text { the system, mature }\end{array}$ & $\begin{array}{c}22.5 \\
(69.5)\end{array}$ & $\begin{array}{c}6.2 \\
(131)\end{array}$ & 39.5 & 632.3 & 5.8 & 42.4 & 0.074 \\
\hline $\begin{array}{l}\text { Nis* } \\
\text { (13388) } \\
12 \text { UTC }\end{array}$ & $\begin{array}{l}\text { southeast of the } \\
\text { system, mature }\end{array}$ & $\begin{array}{l}958.1 \\
(50.8)\end{array}$ & $\begin{array}{l}129.6 \\
(187)\end{array}$ & 22.9 & 704.5 & NA & 42.8 & 1.28 \\
\hline $\begin{array}{l}\text { Szeged } \\
(12982) \\
12 \text { UTC }\end{array}$ & $\begin{array}{l}\text { northern flank of } \\
\text { the system, mature }\end{array}$ & $\begin{array}{l}65.7 \\
(0)\end{array}$ & $\begin{array}{l}2.2 \\
(0)\end{array}$ & 42.5 & 55.6 & 9.4 & 75.1 & 0.014 \\
\hline $\begin{array}{l}\text { Zagreb } \\
(14240) \\
12 \mathrm{UTC}\end{array}$ & $\begin{array}{l}\text { behind the system, } \\
\text { mature }\end{array}$ & $\begin{array}{l}842.8 \\
(0)\end{array}$ & $\begin{array}{l}423.8 \\
(0)\end{array}$ & 35 & 360 & 10.2 & 89.7 & 1.24 \\
\hline $\begin{array}{l}\text { Zadar } \\
(14430)\end{array}$ & early development & $\begin{array}{c}1069.9 \\
(0.8)\end{array}$ & $\begin{array}{l}895.2 \\
(13.2)\end{array}$ & 31.9 & 599.7 & 13.3 & 87.2 & 2.5 \\
\hline
\end{tabular}

* The $985 \mathrm{hPa}$ (27m AGL) level was omitted in the calculation due to not realistic jump in dewpoint.

The MLMR parameter was not available from this sounding.

The hodograph of the storm-relative wind demonstrated a clockwise turn (veering) of the wind from northeasterly-easterly direction at surface to southerly at the $600 \mathrm{hPa}$ level. This suggests the possibility of a strong helical flow at low- and mid-levels in the environment of the thunderstorms (the 0-3-km SREH was 426 $\mathrm{J} / \mathrm{kg}$ ). At the time of the sounding, the direction of the convective system propagation was approximately 30 degrees right of that of the $0-6$ or $0-12-\mathrm{km}$ mean wind. Although the rightward deviation of the motion with respect to mean flow is usual for isolated supercell storms, it is sometimes observed in case of mesoscale convective systems too. It is interpreted as a result of superposition of the mean cloud-layer wind and motion of newly generated convective cells, 
directed in the low level jet (Corfidi et al., 1996, Corfidi, 2003). In the presented case, the direction of motion vector for right-moving supercells calculated with the method of Bunkers (Bunkers et al., 2000) was the closest to the observed MCS propagation vector. We also calculated the motion vector proposed for upwindpropagating MCSs (its direction was nearly half-way between the observed motion vector and the direction of the mean winds). Although the studied system could be rather classified as downwind-propagating, the corresponding vector constructed according Corfidi's proposal (Corfidi, 2003) would have a magnitude of about $63 \mathrm{~m} / \mathrm{s}$ (not shown), which is too high for our case. It is possible that the rightward deviation of the whole system was also influenced by the winds in the cold pool (which where northwesterly at the surface, according the synoptic measurements). Unfortunately, there was no sounding (or other wind observation), which would be representative for the cold pool area and situated directly along the storm track, so this assumption cannot be verified from observations.

Besides soundings, it was also possible to investigate the pre-storm airmass temperature and humidity properties with IASI satellite profiles valid for 09:00 UTC. For example, a profile inferred at the Serbian-Romanian border at Jimbolia (Fig. 7b) showed relatively dry air for the entire troposphere. The relative humidity was everywhere below $55 \%$, the driest tropospheric levels were around $600(30 \%)$ and $500 \mathrm{hPa}(22 \%)$ levels. The air was conditionally unstable, although the CAPE was only about $360 \mathrm{~J} / \mathrm{kg}$.

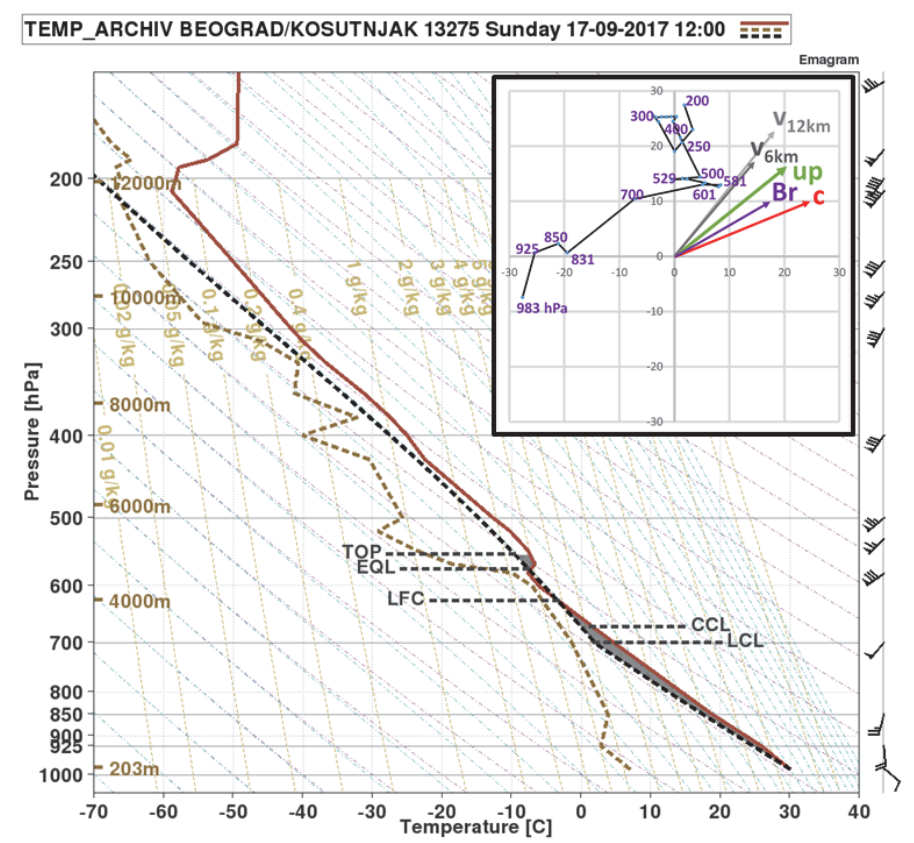

Fig. 7a. Beograd sounding and hodograph of storm-relative wind (shown in rectangle) valid for September 17, 2017, 12:00 UTC. Winds are in $\mathrm{m} / \mathrm{s}$ (the meaning of the barbs is the same as in Fig. 6). The stable (unstable) area of the sounding is shaded by dark (light) grey color. The storm motion is shown by vector $\mathrm{c}$ in the hodograph (the magnitude of the vector is 26.5 $\mathrm{m} / \mathrm{s}$ ). Other vectors $v 6 \mathrm{~km}$ and $\mathrm{v} 12 \mathrm{~km}$ are density averaged winds for $0-6-\mathrm{km}$ and $0-12-\mathrm{km}$ depth, respectively.u $\mathrm{u}_{\mathrm{p}}$ indicates MCS motion vector for upwind propagating systems (Corfidi et al., 1996), $\mathrm{Br}$ is for Bunkers motion vector for right moving supercells (Bunkers et al., 2000). Pressure levels in $\mathrm{hPa}$ are labeled. The start of the hodograph is at the anemometric height $(983 \mathrm{hPa})$. 


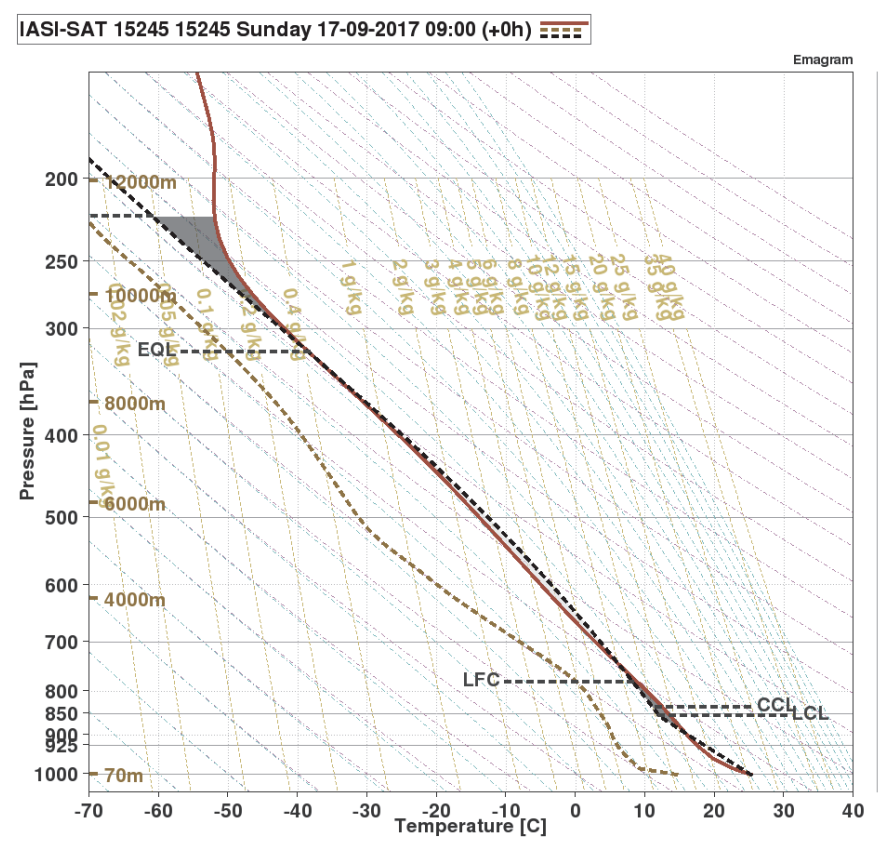

Fig. $7 b$. IASI L2 vertical profile of temperature and dew point valid for the area of Jimbolia station (emphasized in Fig. 2) and for September 17, 2017, 09:00 UTC. The light grey area is for positive CAPE $(362 \mathrm{~J} / \mathrm{kg})$, CIN area is dark grey $(16 \mathrm{~J} / \mathrm{kg})$. DCAPE was estimated as $386 \mathrm{~J} / \mathrm{kg}$.

\section{Development of the storm from radar and satellite observations}

Intense development of deep convection could be observed over Croatia and Bosnia-Hercegovina already in the morning hours of September 17, 2017 (Fig. 8a). A weak precipitation system also passed over the common border of Serbia and Romania, but dissipated fast. There is no information about severe events related to these early convective precipitation bands. However, related precipitation and evaporation could possibly increase the near-surface humidity and support the development of convection in later hours. The origin of the studied convective system could be traced back to convective clouds, which started to develop at around 06:25 UTC over the Adriatic Sea. The environment here was favorable for thunderstorms as indicated by the 00 UTC sounding at Zadar with moderate SBCAPE, reaching $687 \mathrm{~J} / \mathrm{kg}$ and $41 \mathrm{~mm}$ of total precipitable water. According to the mosaic radar imagery, three segments of the convective system (denoted A, B, C) could be tracked, although the convective cells at the leading edge of these segments were not stationary and underwent frequent transition. High radar reflectivity $(>55 \mathrm{dBz})$ in some of these cells was detected already at around 09:00 UTC (Fig. 8b). Thereafter, the direction of the system propagation started to deviate to the right with respect to motion of the previous cells and precipitation systems. At the start of the windstorm at 
11:00 UTC the convective system was quite compact (Fig. 9a), resembling quasi-linear MCSs with trailing stratiform precipitation (TS). However, at around 12:30 UTC (Fig. 9b) its structure changed significantly, the maximum radar reflectivity in each of the segments decreased and some cells dissipated completely. It is possible that in some cases the maximum radar reflectivity was underestimated because of the distance from available radars or because of screening effects, but the weakening of convection and dissipation of cloudiness was recognizable on the satellite imagery as well (not shown). This could have been the result of the intrusion of dry environmental air, which presence was indicated on Belgrade sounding. In Fig. $9 b$ one can also recognize further development of deep convection near the border of Bosnia-Hercegovina, Serbia, and Croatia but the comparison with surface wind observations clearly showed that the windstorm was related to the leading edge of the convective system, denoted by the A,B,C segments.

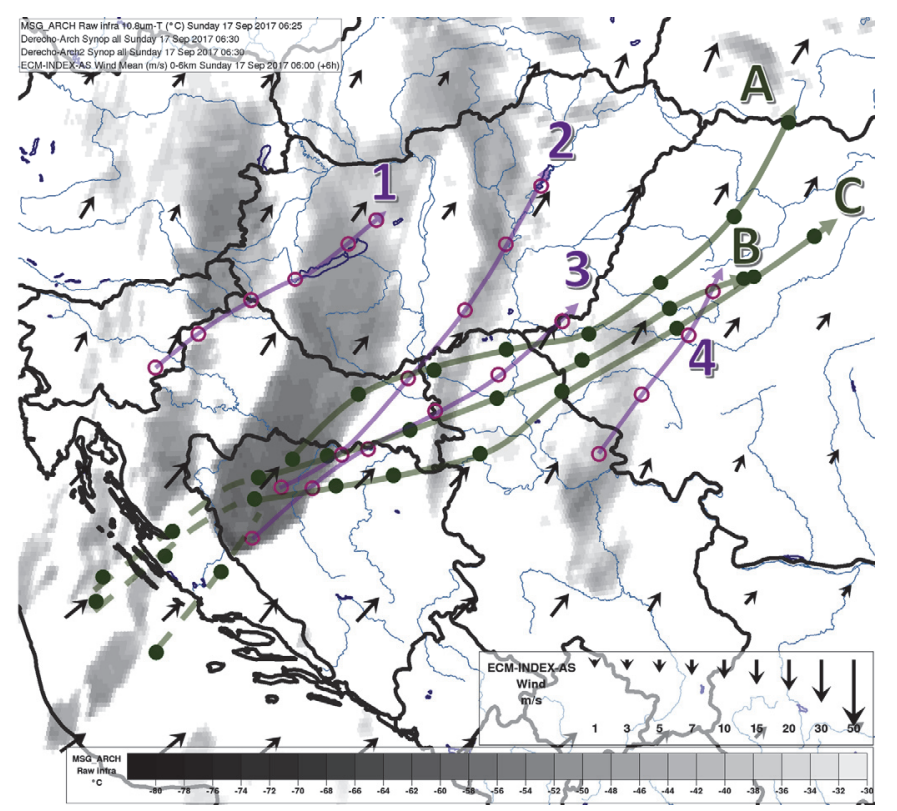

Fig. 8a. Tracks of certain significant storms and segments of the September 17, 2017 convective system (long thick annotated curves with arrowheads). Circles show the positions of the storms (usually the maximum radar reflectivity) with hourly intervals, starting from 06:30 UTC. Labels 1-4 denote those systems, which were not associated with the windstorm, A-C were the segments of the derecho-producing storm. Note that the 06:25-08:25 UTC positions of the A-C segments were only roughly estimated upon satellite imagery, the storms were out of the ranges of available radars at that time. The shades show the cloud-top temperature of the MSG IR $10.8 \mu \mathrm{m}$ channel $\left({ }^{\circ} \mathrm{C}\right)$ valid for 06:25 UTC. Arrows depict the 0-6 km mean wind $(\mathrm{m} / \mathrm{s})$ from the $6 \mathrm{~h}$ forecast of the ECMWF run based on September 17, 2017, at 00:00 UTC. The range of the temperature scale is from $-82{ }^{\circ} \mathrm{C}$ to $-30{ }^{\circ} \mathrm{C}$ by $2{ }^{\circ} \mathrm{C}$. Mean wind vectors of $1,3,5,7,10,15,20,30$, $50 \mathrm{~m} / \mathrm{s}$ are depicted. 


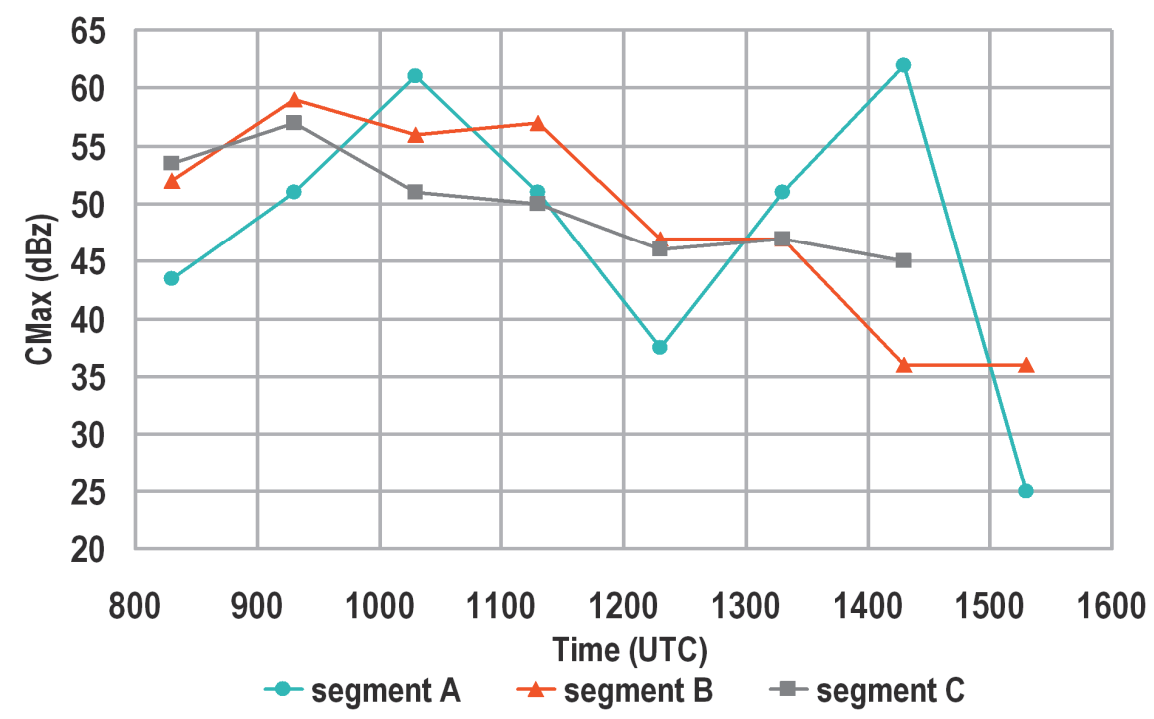

Fig. 8b. Course of the column maximum radar reflectivity (dBz) in the A-C segments of the September 17, 2017 windstorm producing convective system between 08:15 and 15:15 UTC inferred from the mosaic radar imagery of Hungarian, Croatian, and Slovak radars.

Some of the cells of the convective system were remarkably more intense and persistent compared to their neighbors. This was the case of the thunderstorm in the segment $C$ over Serbia between 11:10 and 12:15 UTC exhibiting a forward-flank WER echo around 11:30 UTC (not shown). Another storm could be identified between 13:45 and 14:40 UTC as part of the A segment in western Romania (Fig. 9c). The maximum radar reflectivity reached $67 \mathrm{dBz}$ in this cell according the Tarnaveni radar and a WER echo could be found at 14:00 and 14:15 UTC (Figs. 10a, 10b and 10c). A notable feature was a small-scale (30 km in direction perpendicular to its propagation) bow echo, which also started to develop after 13:45 UTC and a weak echo in radar reflectivity behind it, observed from both Hungarian and Romanian radars. This bow echo passed over the city of Huedin, where $40 \mathrm{~m} / \mathrm{s}$ peak gust was observed. It is probable that the above mentioned intense storms were supercells, which developed at the leading edge of the convective system, although there are no such Doppler radar velocity data, which would undoubtedly confirm the presence of mesocyclone in these storms. 

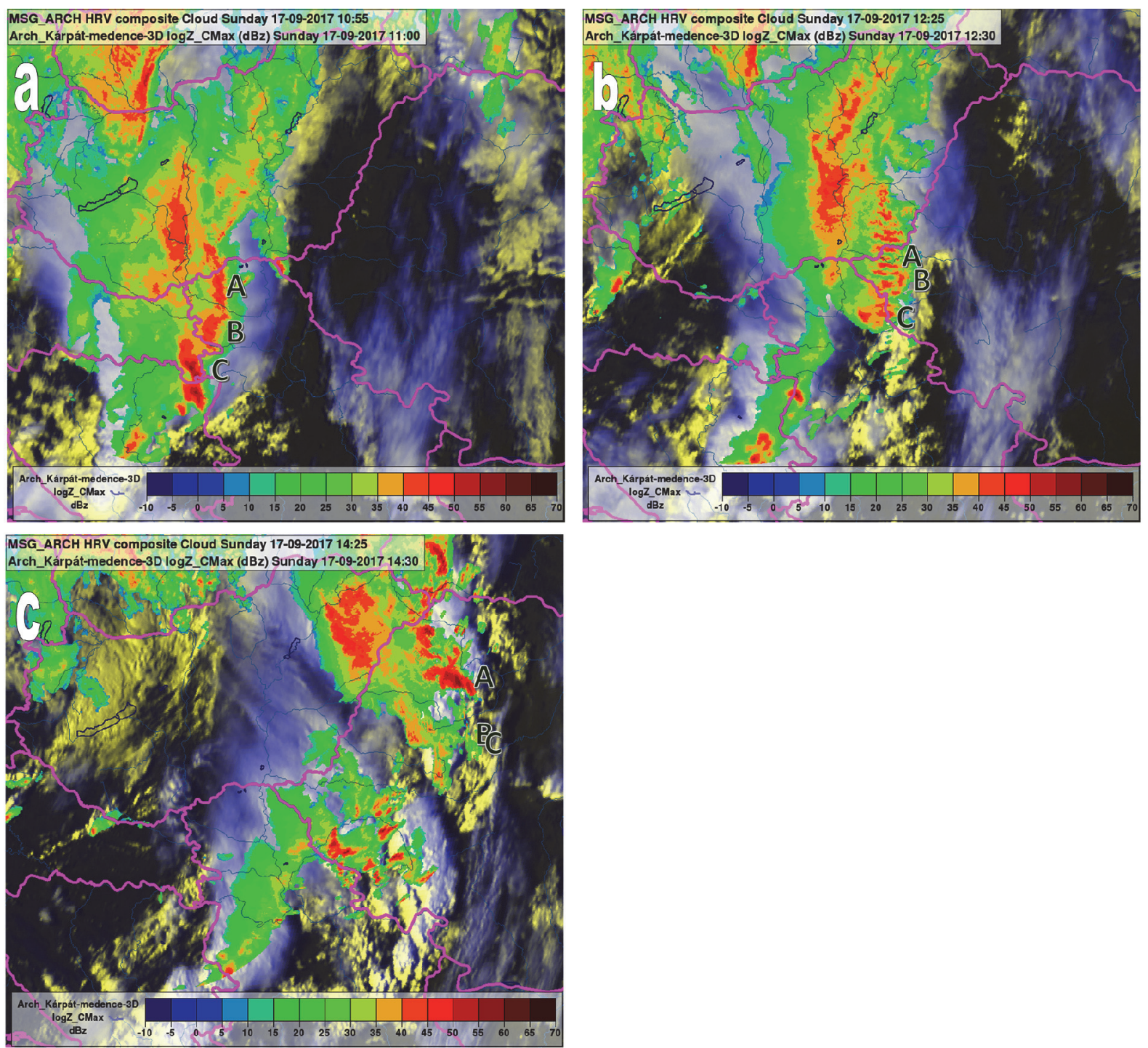

Fig. 9a. MSG 'HRV cloud' composite image valid for September 17, 2017, 10:55 UTC and column maximum radar reflectivity $(\mathrm{dBz})$ of the mosaic radar imagery valid for 11:00 UTC (color shades). Labels A, B, C denote the segments of the derecho-producing convective system. The range of the reflectivity scale is from -10 to $70 \mathrm{dBz}$ by $5 \mathrm{dBz}$.

Fig. 9b. As in Fig. $9 a$ but for 12:25 (12:30) UTC.

Fig. 9c. As in Fig. $9 a$ but for 14:25 (14:30) UTC. 


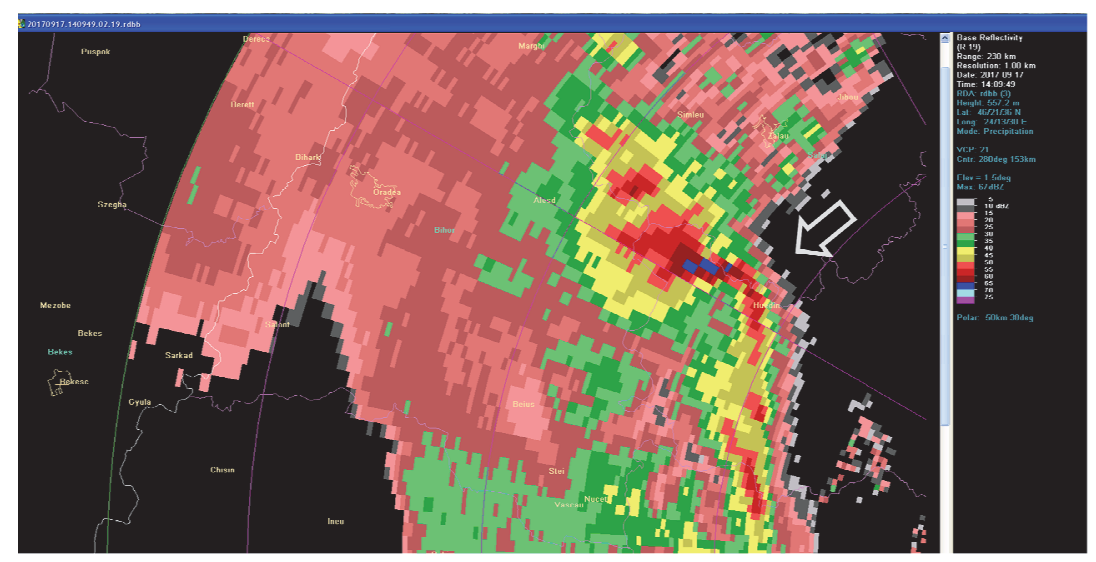

Fig. 10a. Detail from the Tarnaveni radar imagery (west Romania) showing the PPI $1.5^{\circ}$ measurement of radar reflectivity on September 17, 2017, at 14:10 UTC in the region of Huedin city. The shades of radar reflectivity start at $5 \mathrm{dBz}$ (light grey), the colors change for $15 \mathrm{dBz}$ (pink), $30 \mathrm{dBz}$ (green), $40 \mathrm{dBz}$ (yellow), $50 \mathrm{dBz}$ (light red), and $65 \mathrm{dBz}$ (blue). The maximum measured value was $67 \mathrm{dBz}$. The arrow points toward the small-scale bow echo pattern on the right flank of an intense (probably supercell) storm.

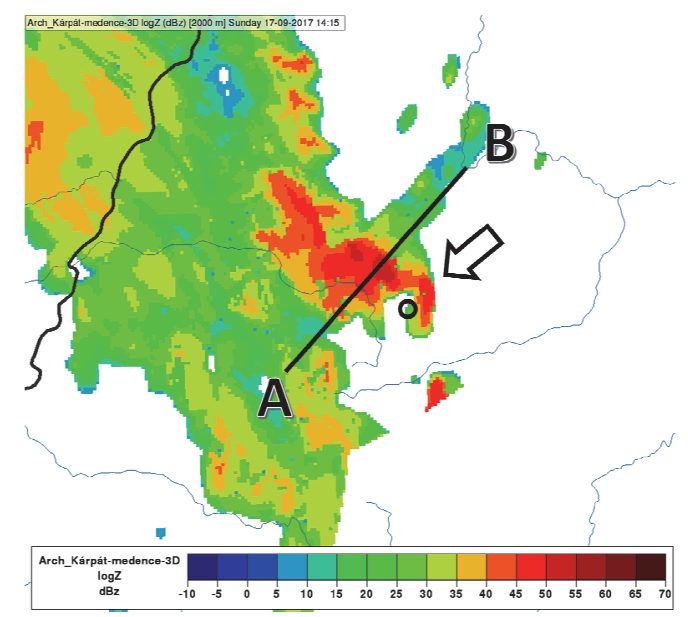

Fig. 10b. $2 \mathrm{~km}$ CAPPI reflectivity of the mosaic radar imagery (shades, dBz) valid for September 17, 2017, 14:15 UTC with the depicted sense of the AB cross-section in Fig. 10c. The arrow points toward the bow echo pattern. The circle shows the position of Huedin (where $40 \mathrm{~m} / \mathrm{s}$ gust was observed). The range of the reflectivity scale is from -10 to $70 \mathrm{dBz}$ by $5 \mathrm{dBz}$.

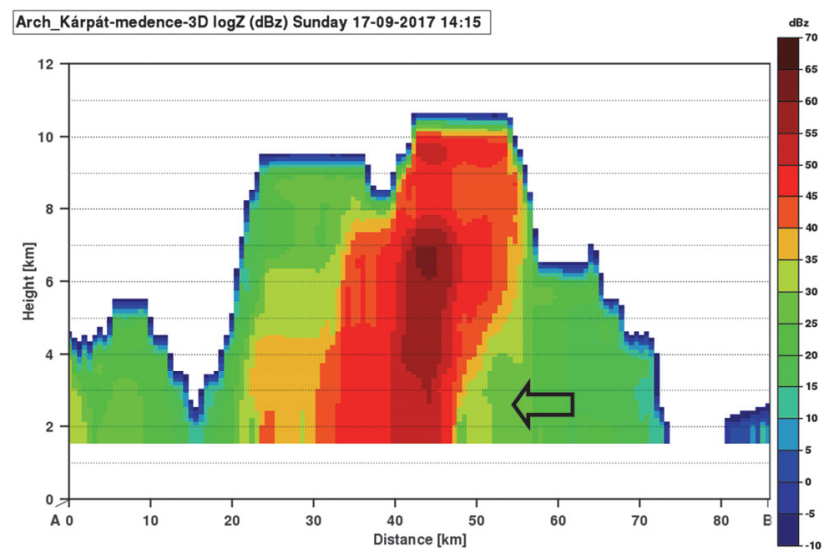

Fig. 10c. Vertical cross-section through the mosaic radar reflectivity field valid for September 17, 2017, 14:15 UTC (the sense of the section is depicted in Fig. 10b). The arrow points toward the WER echo pattern on the forward flank of the storm. 


\section{Impact of the storm}

First damage reports, which could be associated with the studied windstorm were from the border region of Serbia, Croatia, and Bosnia-Hercegovina (website of the European Severe Weather Database, hereafter ESWD 2019). However, there were no details further specifying the character of this damage. More information is from northern Serbia, mainly from the region between Beograd and Novi Sad (affected by the C segment of the system). Reports about injured people (at least 2 cases) were from the region north of Beograd (ESWD, 2019). There were also several videos available on the internet (youtube.com, 2017) showing for example a detached roof of a house transported by wind in Hrtkovci (Nevreme $\mathrm{u}$ Hrtkovcima 1) and falling of a tree on the road at Tomaševac (Nevreme (Tornado)-Srbija on September 17,2017 (Okolina Zrenjanina-Tomasevac)). Damage by wind was reported at least from 21 cities and villages. The most detailed information about the storm impact was from Romania (Disaster Management of Romania: Inspectoratul General pentru Situatii de Urgenta, IGSU, personal communication). Between September 17, 2017, 12:00 UTC and September 18, 2017, 03:00 UTC, windstorm damages and consequences were reported in 212 localities from 15 counties (Alba, Arad, Bihor, Bistriţa-Năsăud, Braşov, Cluj, Hunedoara, Harghita, Iaşi, Maramureş, Mureş, Suceava, Sălaj, Timiş). During the storm, 8 people deceased (Arad 1, Bistrica-Năsăud 2, Timiş 5 cases) and 137 were injured (Alba 6, Arad 15, Bihor 35, Hunedoara 1, Maramureş 10, Sălaj 1, Timiş 49). At least 116 dwellings were affected in Timiş and Sălaj counties, over 290 trees were taken down on roads, cars and buildings with a totally of 35 vehicles damaged, 137 roofs were partially or totally affected by the strong wind gusts. Ministry of Internal Affairs forces intervened to rescue 204 people (in the counties of Alba, Arad, Bihor, Bistriţa-Năsăud, Cluj, Hunedoara, Maramureş, Sălaj, Timiş, and Maramureş). The spatial distribution of the material damage, number of injured people, and casualties are shown in Fig. 11a. The forestery reported $460000 \mathrm{~m}^{3}$ of fallen trees, from this $246000 \mathrm{~m}^{3}$ occurred on compact area (Regia Nationala a Padurilor, Romsilva, personal communication). The national road management service reported that road traffic was disrupted on 12 national roads (DN1, DN6,DN7, DN13B, DNI7C, DN18, DN18B, DN58, DN 68, DN 69, DN 79, DN79A) and 6 county roads (DJ795, DJ107P, DJ688, DJ764B, DJ79B, DJ 708) due to falling trees (Fig. 11b). Furthermore, 42 railway sections were affected due to falling trees in the regional area of Timişoara, Cluj, Braşov, and Iaşi and 42 school units were closed on September 18, 2017 (Arad 1, Bihor 18, Cluj 1, Timiş 22) as a result of severe weather consequences. The damage distribution indicates a widespread impact of the storm, which was related not only to the most intense convective cells (e.g., in segment A), although their contribution to the total damage was probably the largest. 


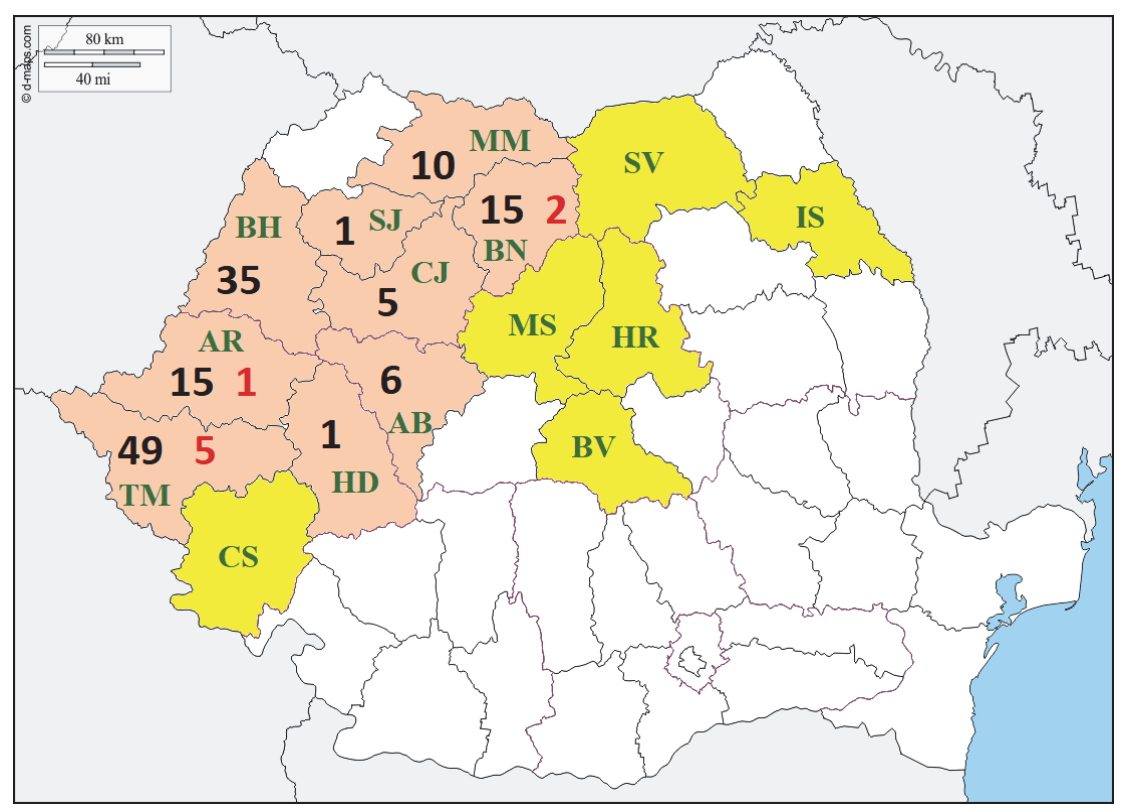

Fig. 11a. Impact of the September 17, 2017 windstorm in Romania. Yellow shade shows counties, where only material damage was reported, in orange-shaded counties there were also injured people (black numbers) or casualties (red numbers). The abbreviations of the counties are as follows: CS-Caraş, TM-Timiş, AR-Arad, BH-Bihor, HD-Hunedoara, ABAlba, CJ-Cluj, SJ-Sălaj, MM-Maramureş, BN-Bistrica-Năsăud, MS-Mureş, HRHarghita, BV-Braşov, SV-Suceava, IS-Iaşi. The source of the background chart: Dmaps.com, https://d-maps.com/carte.php?num car=5808\&lang=en

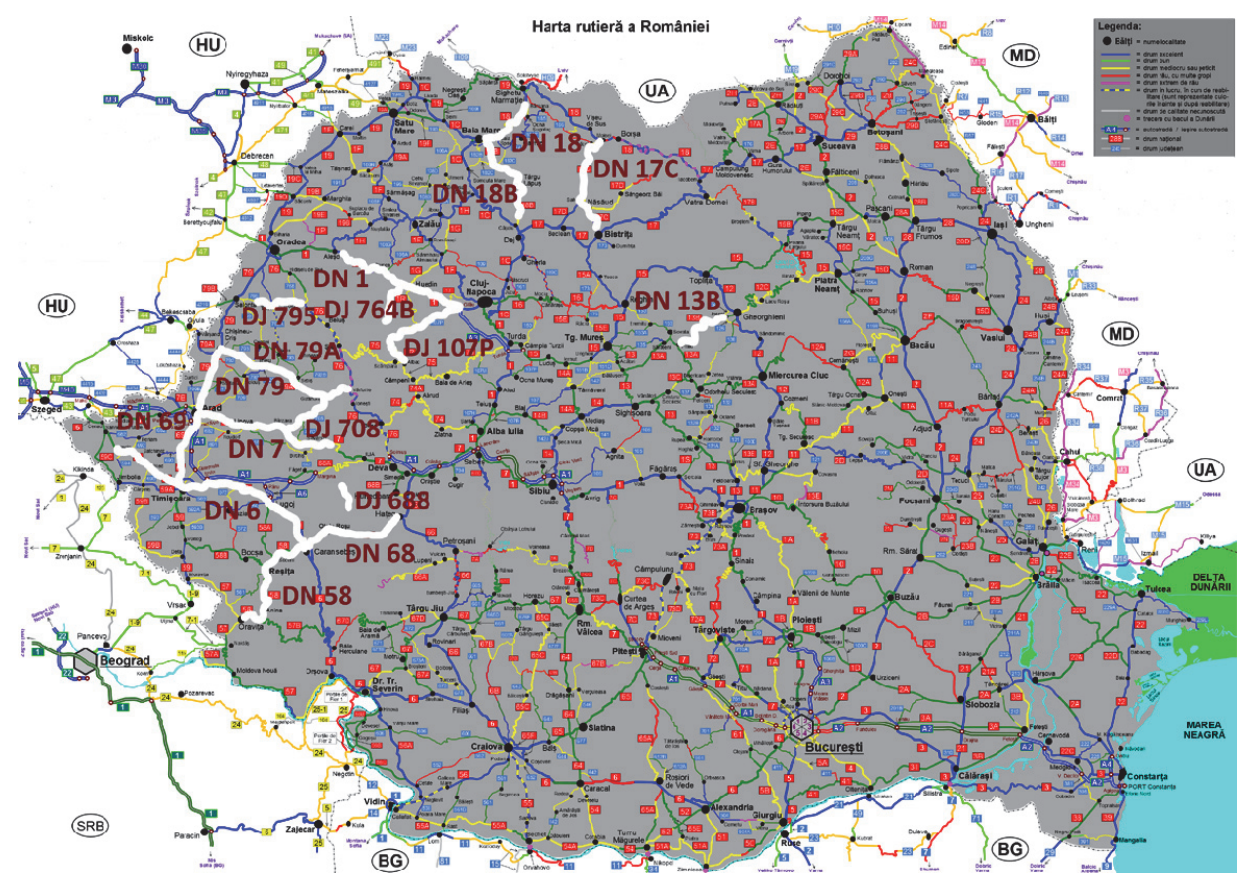

Fig. 11b. Closed roads (thick white lines) in Romania due to the September 17, 2017 windstorm consequences. Road numbers are also shown.

Source: forum.construim-romania.ro 
According to ESWD, the studied windstorm probably affected also some areas in Ukraine, in the border region with Romania. A weak (F0 intensity) tornado was reported from Velikyj Bychkiv at around 16:00 UTC (ESWD, 2019). The windstorm caused also several damages in Hungary, in the border area with Romania, mainly in the Békés county (data of the National Disaster Management Directorate General in Hungary). There were at least 44 interventions of the disaster management, which were concentrated near the city of Békéscsaba (due to uprooted trees, broken branches, and consequent damages on cars, electric power lines, and roofs of houses).

\section{Convective parameters and characteristics of the pre-storm environment}

Because there were only few representative soundings in the area of the storm, the distribution of humidity and instability parameters was studied with use of ECMWF analyses and forecasts as well. These enabled to follow the environmental conditions of the storm along its lifetime. We also tried to depict the storm-relative flow in order to identify the areas, which could have been the sources of moisture/dryness and instability. On the $950 \mathrm{hPa}$ specific humidity charts it was possible to see that the studied convective system travelled from relatively moist $(10 \mathrm{~g} / \mathrm{kg})$ area over Croatia toward much drier $(6 \mathrm{~g} / \mathrm{kg})$ environment over Serbia on September 17, 2017, at 09:00 UTC (Fig. 12a). Very similar was the distribution of the ECMWF-calculated MUCAPE (Fig. 12d), which coincided with the moist areas near the surface. At 12:00 UTC one can register that the band of moister air moved towards east. Still, there was drier (6-9 g/kg) air on the eastern and southern side of the convective system, mainly over southern Serbia and its border to Romania. However, at the $950 \mathrm{hPa}$ level the storm-relative flow was northeasterly, hence, the northern part of the system encountered somewhat moister (around $9 \mathrm{~g} / \mathrm{kg}$ ) air from southeastern Hungary and its adjacent border territory with Romania (Fig. 12b). Similarly to specific humidity, also the area with non-zero MUCAPE progressed towards east (Fig. 12e). The model-inferred MUCAPE values were rather low (mostly around $100 \mathrm{~J} / \mathrm{kg}$ ).

At 14:00 UTC the drier air was present over the central part of Romania (Fig. 12c), while the area, where the system propagated and tended was rather moist. At that time it is already possible to see higher values of MUCAPE on the downstream side of the system (Fig. 12f) and also in the area of the newly developed convective cloud system over the northern part of Serbia. 

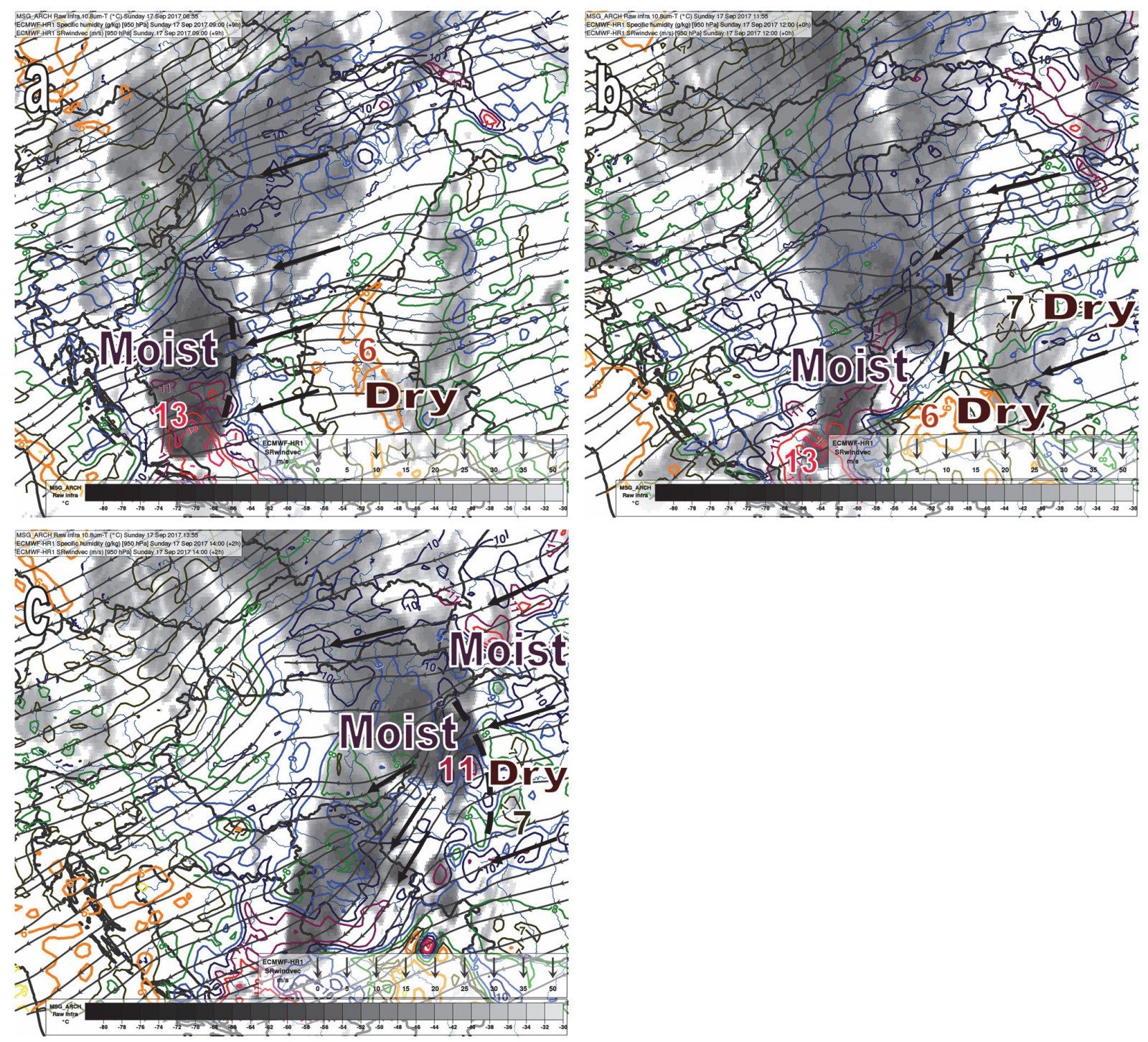

Fig. 12a. ECMWF 9h forecast of $950 \mathrm{hPa}$ specific humidity (colored lines range by $1 \mathrm{~g} / \mathrm{kg}$, the $6 \mathrm{~g} / \mathrm{kg}$ is emphasized by thicker orange line) and of storm-relative wind (streamlines) valid for September 17, 2017, 09:00 UTC. The MSG IR 10.8 $\mu \mathrm{m}$ channel image (shades, ${ }^{\circ} \mathrm{C}$ ) from 08:55 UTC is in the background. The moist and dry low-level air regions are highlighted, the thick dashed line shows the position of the leading edge of the convective system (convergence line). Some humidity lines are labeled with big letters for easier identification of the moist and dry areas. The thick arrows denote the direction of the streamlines in the neighborhood of the system.

Fig. 12b. As in Fig. 12a. but for September 17, 2017, 12:00 UTC and September17, 2017, 12:00 UTC ECMWF analyses.

Fig. 12c. As in Fig. 12a. but for September 17, 2017, 14:00 UTC and for the $+2 \mathrm{~h}$ forecast of the September 17, 2017, 12:00 UTC run of the ECMWF model. 

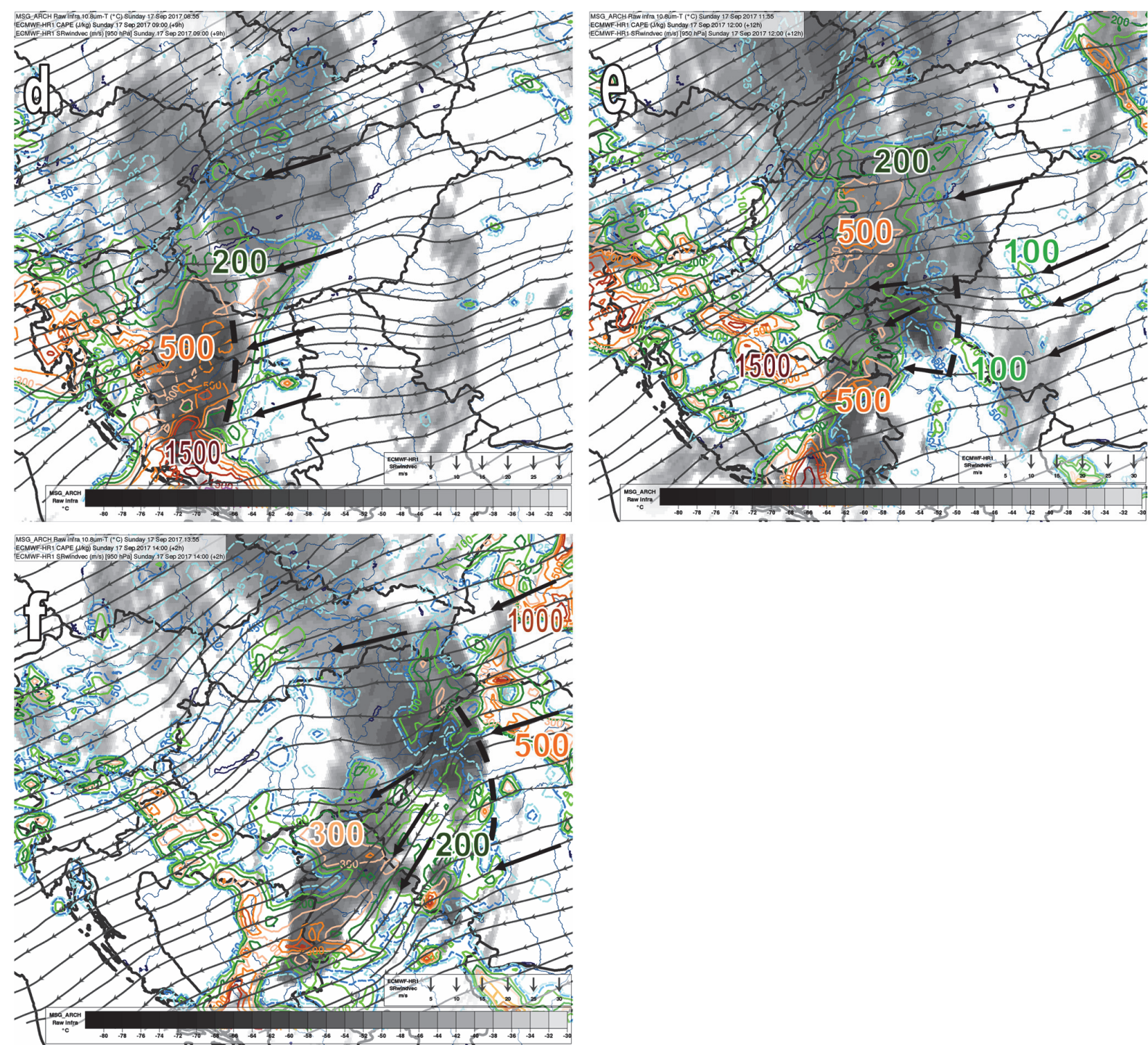

Fig. 12d. As in Fig. 12a. but for MUCAPE contours (25, 50, 100, 200, 300, 500, 750, $1000,1500,2000 \mathrm{~J} / \mathrm{kg}$ ). Some lines are labeled with big letters for easier identification of forecast MUCAPE in the system and its environment.

Fig. 12e. As in Fig. 12d. but for September 17, 2017, 12:00 UTC and for the $+12 \mathrm{~h}$ forecast of the September 17, 2017, 00:00 UTC run of the ECMWF model.

Fig. 12f. As in Fig. 12d. but for September 17, 2017, 14:00 UTC and for the $+2 \mathrm{~h}$ forecast of the September 17, 2017, 12:00 UTC run of the ECMWF model.

If we look at the relative humidity conditions at the $950 \mathrm{hPa}$ level at 12:00 UTC (Fig. 13a), we can see that the air at the southern and eastern flank of the system was much less saturated (20-40\%) than the storm-relative inflow area (about 60\%). However, with increasing height, the situation changed and at $700 \mathrm{hPa}$ the storm-relative flow was easterly-southeasterly (Fig. 13b), pointing toward the storm from the area with low relative humidity. Both specific and relative humidity distributions indicate that the northern part of the system encountered moister air at low levels and persisted, whereas the thunderstorms on its southern flank quickly dissipated due to inflow of dry, unsaturated environmental air. 


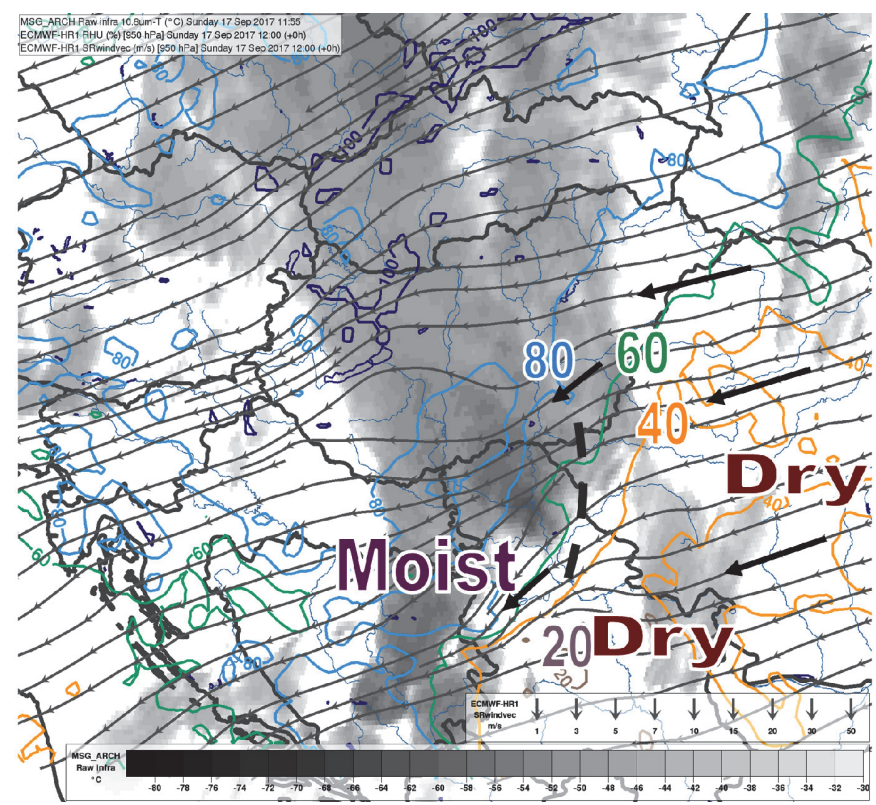

Fig. 13a. As in Fig. 12b. but for the contours of the $950 \mathrm{hPa}$ relative humidity (by 20\%). Some humidity lines are labeled with big letters for easier identification of the relatively moist (more saturated) and dry areas. Thick arrows denote the direction of the streamlines in the neighborhood of the system.

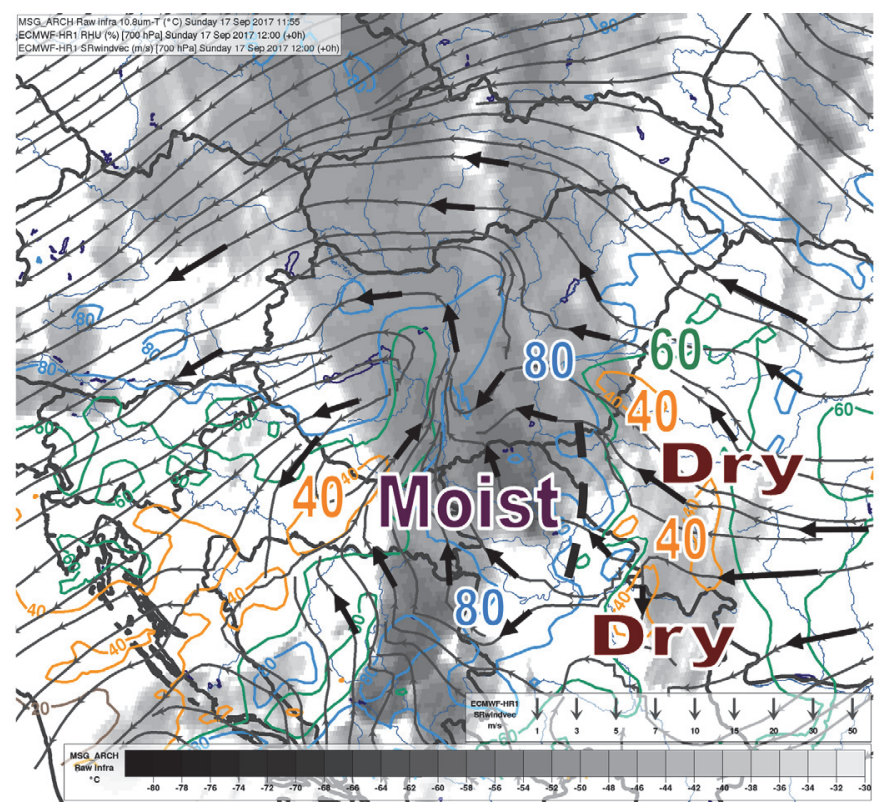

Fig. 13b. As in Fig. $13 \mathrm{a}$ but for the $700 \mathrm{hPa}$ relative humidity and $700 \mathrm{hPa}$ streamlines of the storm-relative wind.

It was already mentioned that the thunderstorms developed along a surface line of convergence, which was moving together with the system. The low level wind convergence was visible also in the model analyses at the $925 \mathrm{hPa}$ level and relatively wide area of ascending motions was diagnosed at $800 \mathrm{hPa}$ (Fig. 14a). On the southwest-northeast vertical cross-section (Fig. 14b) it is shown that these motions extended over a large portion of the troposphere. The occurrence of ascending vertical motions coincided with an upper-air potential vorticity (PV) 
anomaly, which could be also detected on the section. We hypothesize that these motions could provide some additional lift for generating convection in the midtroposphere. Although, it is probable that during the mature stage of the storm, the main sources of lift were the convective system itself and its outflow.

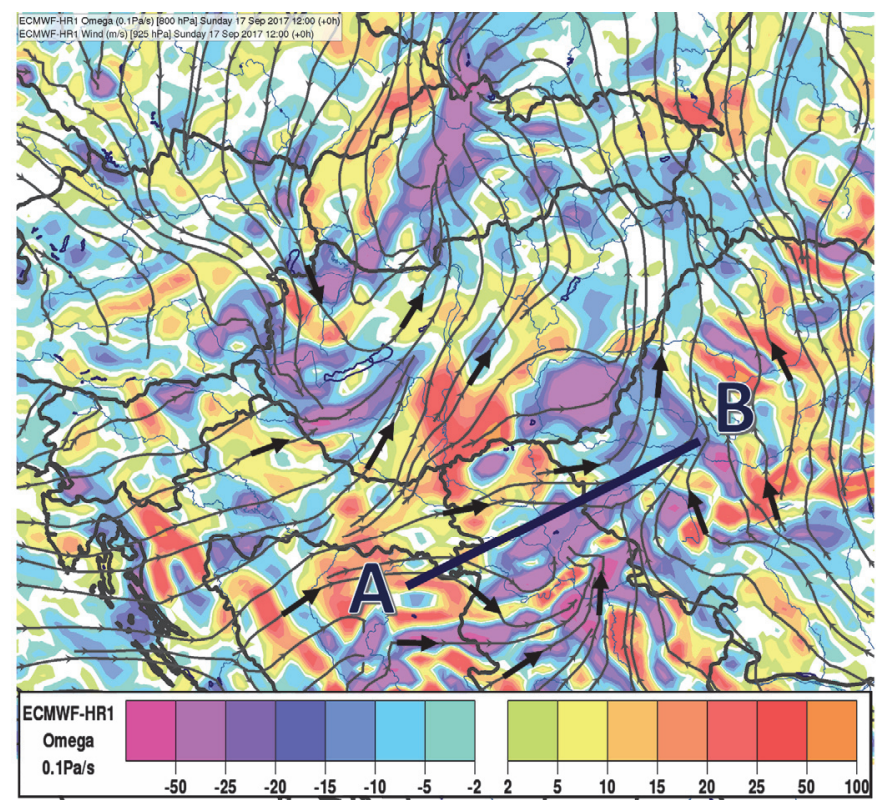

Fig. 14a. ECMWF September 17, 2017, 12:00 UTC analysis of $800 \mathrm{hPa}$ vertical motions (Omega, shades, $0.1 \mathrm{~Pa} / \mathrm{s}$ ) and $925 \mathrm{hPa}$ wind (streamlines, $\mathrm{m} / \mathrm{s}$ ). The AB line shows the sense of the cross-section in Fig. 14b. The range of the vertical motions scale is from $-55 \cdot 10^{-1}$ to $-2 \cdot 10^{-1} \mathrm{~Pa} / \mathrm{s}$ (lilac and bluish shades) and from $2 \cdot 10^{-1}$ to $100 \cdot 10^{-1} \mathrm{~Pa} / \mathrm{s}$ (green, yellow and red shades). The thick arrows denote the direction of the streamlines in the neighbourhood of the system.

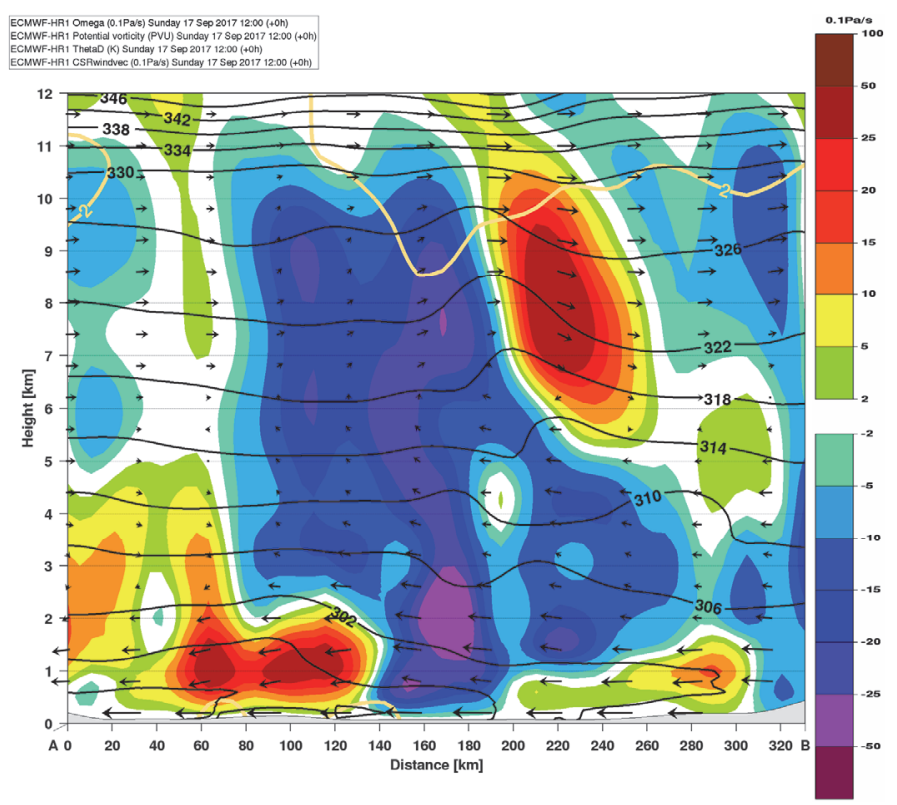

Fig. 14b. Vertical cross-section of the September 17, 2017, 12:00 UTC ECMWF analysis of vertical motions (Omega, shades, $0.1 \mathrm{~Pa} / \mathrm{s}$ ), potential temperature (lines by $4 \mathrm{~K}$ ), potential vorticity (only 2 PVU is contoured by thicker light brown line), and stormrelative wind (arrows, $\mathrm{m} / \mathrm{s}$ ) projected to the cross-section plane. The sense of the section was shown in Fig. 14 a. 
The above presented model outputs give some explanation on the persistence of deep convection from humidity point of view and concerning lift. However, there is uncertainty in the significance of the environmental (conditional) instability and magnitude of CAPE. Although the model outputs indicate that there was at least low CAPE behind the leading edge of the storm, the pre-storm instability is important for the generation of new cells. The magnitude of CAPE (and of several versions of this parameter) largely depends on the surface or near-surface humidity conditions (dew-point), which is often uncertain. That is why we also examined temperature lapse rates between the 600-925 and 400-700 hPa levels. At 12:00 UTC, the 600-925 hPa lapse rate was especially high in the dry, unsaturated air, somewhere it was almost dryadiabatic (Fig. 15a). At mid-levels, the unstable area extended more towards north, lapse-rates around $7 \mathrm{~K} / \mathrm{km}$ could be usually found along the track of the storm $($ Fig 15 b).

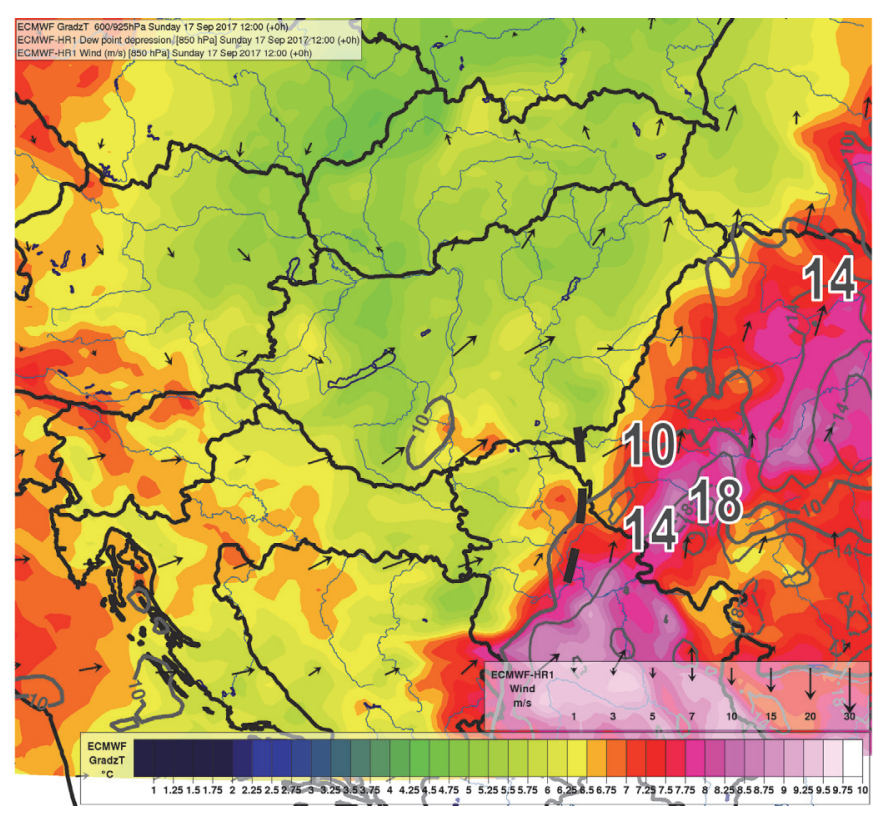

Fig. 15a. ECMWF September 17, 2017, 12:00 UTC analysis of the 600-925 hPa lapse rate (shades, $\mathrm{K} / \mathrm{km}$ ), $850 \mathrm{hPa}$ dew point depression (lines above $10 \mathrm{~K}$ which is emphasized by thicker contour), and $850 \mathrm{hPa}$ wind (arrows, $\mathrm{m} / \mathrm{s}$ ). The range of the lapse rate scale is from $0.75 \mathrm{~K} / \mathrm{km}$ to $10 \mathrm{~K} / \mathrm{km}$ by $0.25 \mathrm{~K} / \mathrm{km}$. Yellow shades belong to lapse rate bigger than $6 \mathrm{~K} / \mathrm{km}$, orange shades start from $7 \mathrm{~K} / \mathrm{km}, 8 \mathrm{~K} / \mathrm{km}$ rate is in magenta color, etc. Wind vectors of 1,3 , $5,7,10,15,20,30 \mathrm{~m} / \mathrm{s}$ are depicted. Big labels show contours of dew point depression of 10 , $14,18 \mathrm{~K}$. The thick dashed line shows the position of the leading edge of the convective system. 


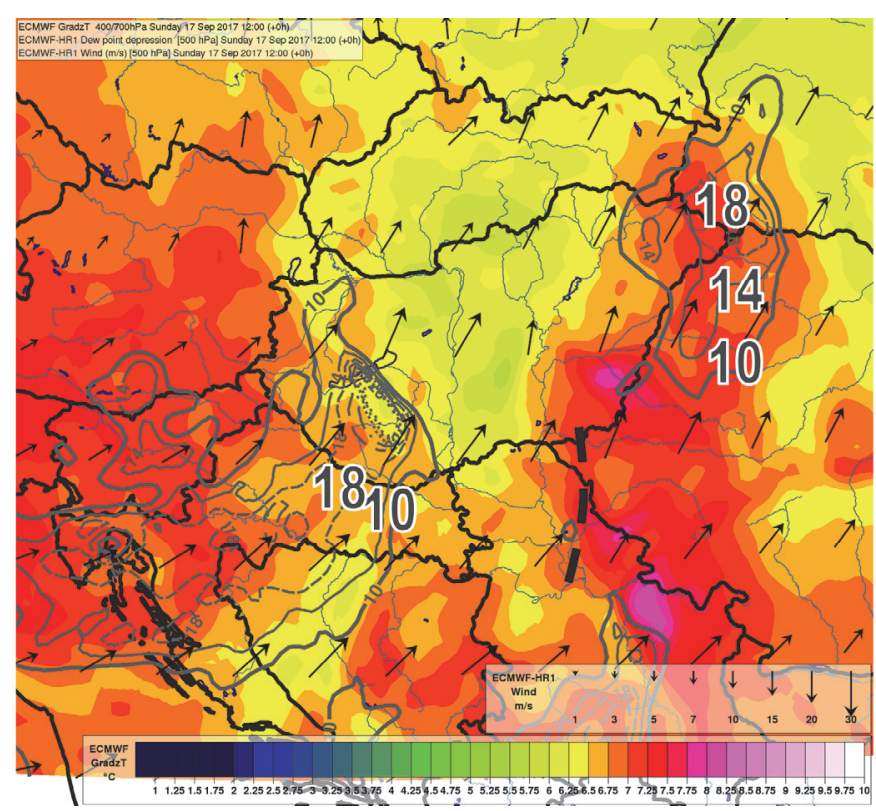

Fig. 15b. As in Fig. 15a. but for the 400-700 hPa lapse rate, $500 \mathrm{hPa}$ dew point depression, and $500 \mathrm{hPa}$ wind.

It must be also taken into account that the model-derived and observed near-surface temperature and humidity conditions can be different, and this can largely influence CAPE calculations. To check this, we evaluated the model outputs (both analysis and forecast) of surface-based CAPE (SBCAPE) at the points with synoptic observations in the pre-storm environment. We recalculated the SBCAPE with a surface parcel starting from the observed temperature, dewpoint, and pressure values (Table 4). This evaluation showed that the model $2 \mathrm{~m}$ temperature and dew-point were underestimated in average, though their BIAS was not very high. This had an impact on the SBCAPE values, which became higher in average, after the correction. The increase in CAPE (in a few pseudotemps it was even exceeding $1000 \mathrm{~J} / \mathrm{kg}$ ) was visible for example at stations close to the convective system, because of higher dew points (up to $16{ }^{\circ} \mathrm{C}$ ). The maximum-unstable CAPE (MUCAPE) values were mostly close to SBCAPE or identical (therefore not shown). The comparison with IASI profiles showed that the ECMWF forecasts based on the 00:00 UTC run were moister in the mid- and upper tropospheric levels compared to the satellite measurements at several pre-storm locations (compare Fig. $7 b$ and Fig. 16). It is possible that in the reality, the area of dry mid- and upper-tropospheric airmass was larger than the predicted, covering bigger areas of northern Serbia and western Romania. 
Table 4. Mean temperature and dew point BIAS of the ECMWF analysis and forecast valid to September 17, 2017, 12:00 UTC and with respect to 25 synoptic observations in the pre-storm area. Surface-based CAPE was calculated and averaged for both reference outputs (pseudotemps) and with a corrected surface parcel starting with temperature, dew-point, and pressure values observed at the respective stations. SBCIN values are shown in parenthesis.

\begin{tabular}{lcccc}
\hline \hline & $\begin{array}{l}\text { 2m temperature } \\
\text { BIAS }\left({ }^{\circ} \mathbf{C}\right)\end{array}$ & $\begin{array}{l}\text { 2m dew point } \\
\text { BIAS }\left({ }^{\circ} \mathbf{C}\right)\end{array}$ & $\begin{array}{l}\text { SBCAPE (SBCIN) } \\
(\mathbf{J} / \mathbf{k g})\end{array}$ & $\begin{array}{l}\text { corrected SBCAPE } \\
(\mathbf{S B C I N})(\mathbf{J} / \mathbf{k g})\end{array}$ \\
\hline \hline $\begin{array}{l}\text { ECMWF } \\
\text { analysis }\end{array}$ & -0.98 & -0.11 & $370.56(94.67)$ & $646.24(57.51)$ \\
$\begin{array}{l}\text { ECMWF 12h } \\
\text { forecast }\end{array}$ & -0.34 & -0.27 & $402.76(54.33)$ & $660.16(41.63)$ \\
\hline
\end{tabular}

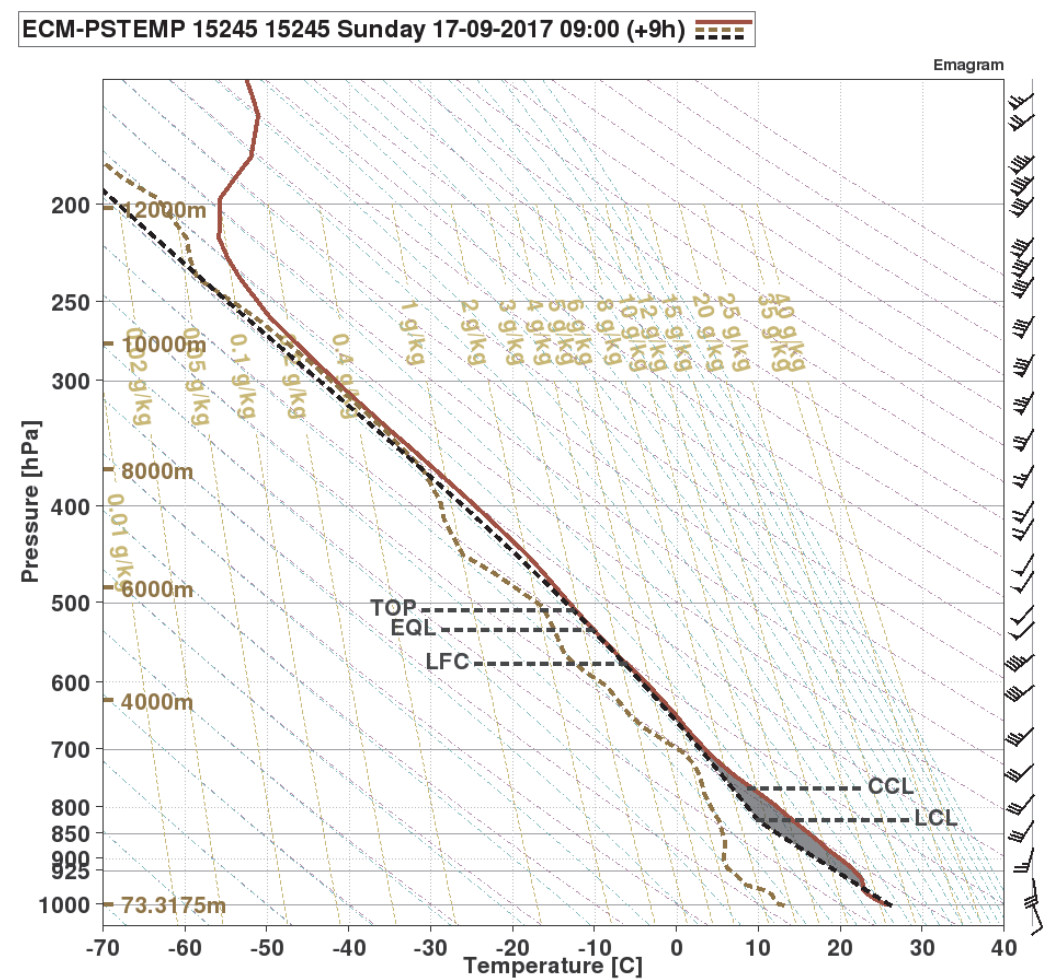

Fig. 16. As in Fig. $7 b$ but inferred from the 9h forecast of the September 17, 2017, 00:00 UTC run of the ECMWF model valid for Jimbolia (Romania).

The intensity of the convective downdrafts and outflows is often studied with the DCAPE parameter, despite of uncertainties in its calculation (Gilmore and Wicker, 1998). Dry environment with high lapse rate also implies high DCAPE values. Already at 09:00 UTC it was possible to diagnose $350-400 \mathrm{~J} / \mathrm{kg}$ DCAPE over Croatia and Bosnia-Hercegovina (not shown). At 12:00 UTC (Fig. 17), the magnitude of DCAPE was even bigger according to the ECMWF analyses (exceeding $500 \mathrm{~J} / \mathrm{kg}$ ) in the pre-storm region. The presence of dry air at 
low levels also resulted in low MLCAPE (mostly below $100 \mathrm{~J} / \mathrm{kg}$, see Table 5). It is noteworthy that the analyzed ECMWF 0-6-km wind shear was significantly (by $5-10 \mathrm{~m} / \mathrm{s}$ ) lower compared to the measurements of the Beograd or Szeged 12:00 UTC soundings (refer to Table 3). The 12:00 UTC ECMWF analysis chart (not shown) indicated that the deep-layer shear was higher on the northern flank of the storm track (along the Hungarian-Romanian border), which could also contribute to better persistence of thunderstorms in this area.

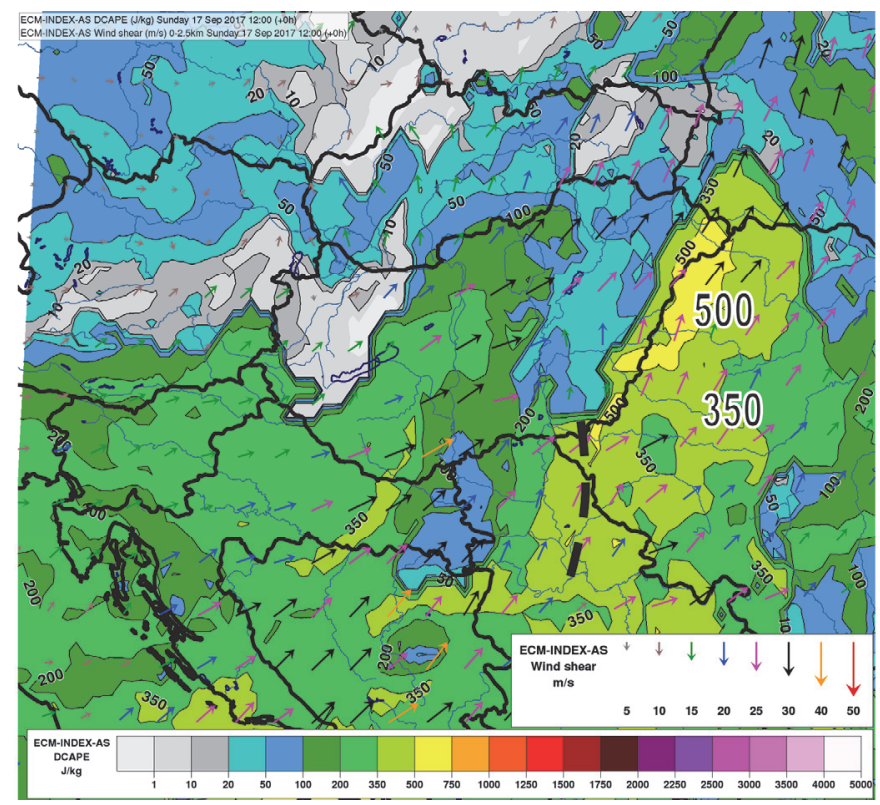

Fig. 17. ECMWF September 17, 2017, 12:00 UTC analysis of DCAPE (shades, J/kg) and 0-2.5 km wind shear (arrows, m/s). Big labels show contours of DCAPE of 350 and $500 \mathrm{~J} / \mathrm{kg}$. The range of the DCAPE scale is from 0 to $5000 \mathrm{~K} / \mathrm{km}$ specified by values of $1,10,20,50$, $100,200,350,500,750,1000,1250,1500,1750,2000,2250,2500,3000,3500,4000$, $5000 \mathrm{~J} / \mathrm{kg}$. The meaning of the thick dashed line is the same as in Figs. 12, 13, and 15 .

Table 5. Minimum, maximum, and average values of some convective and environmental parameters derived from 25 pseudotemps in the pre-storm area and valid for the September 17, 2017, 12:00 UTC ECMWF model analysis.

\begin{tabular}{lllllllll}
\hline \hline parameter & $\begin{array}{l}\text { MLCAPE } \\
(\mathbf{J} / \mathbf{k g})\end{array}$ & $\begin{array}{l}\text { MUCAPE } \\
(\mathbf{J} / \mathbf{k g})\end{array}$ & BLI & $\begin{array}{l}\mathbf{0 - 6 - k m} \\
\text { shear } \\
(\mathbf{m} / \mathbf{s})\end{array}$ & $\begin{array}{l}\mathbf{0 - 6 - k m} \\
\text { mean wind } \\
(\mathbf{m} / \mathbf{s})\end{array}$ & $\begin{array}{l}\text { DCAPE } \\
(\mathbf{J} / \mathbf{k g})\end{array}$ & $\begin{array}{l}\mathbf{0 - 3}-\mathbf{k m} \\
\mathbf{R H} \\
\mathbf{( \% )}\end{array}$ & DCP \\
\hline \hline minimum & 0 & 10 & -5.1 & 23.5 & 15.6 & 286 & 28.8 & 0.02 \\
maximum & 356 & 939 & 0.3 & 36.1 & 22.7 & 505 & 64.1 & 0.98 \\
average & 69.6 & 387.8 & -2.06 & 30.1 & 19.7 & 398.2 & 46.6 & 0.53 \\
\hline
\end{tabular}


For some years, there was a debate among scientists about the importance of the equilibrium between the environmental low-level wind shear and horizontal vorticity provided by the cold-pool negative buoyancy (e.g., Bryan et al., 2006; Coniglio et al., 2012). The RKW theory (Rotunno et al., 1988) says that such equilibrium favors development of upright updrafts:

$$
\begin{gathered}
\Delta u^{2}=c^{2}, \\
c^{2}=2 \int_{0}^{H}(-B) d z,
\end{gathered}
$$

where $\Delta u$ is the environmental wind shear, $c$ is the velocity of the net buoyant generation of vorticity, $B$ is the buoyancy, and $\mathrm{H}$ is the depth of the cold pool. The theory was later extended by the inclusion of the rear-inflow-jet effects and coldpool shear (Weisman, 1992). However, the existence of this equilibrium is not an ultimate condition for the persistence of a convective system. First, we integrated the negative buoyancy through a $2 \mathrm{~km}$ deep layer from the Beograd 12:00 UTC sounding. For the cold pool representation, we used the wet adiabat, which ended at surface at $20.4{ }^{\circ} \mathrm{C}$ temperature - measured at the Beograd Vračar station (13274) at 13:00 UTC in the cold pool. The integrated negative buoyancy was $-357.74 \mathrm{~J} / \mathrm{kg}$, and the corresponding velocity $c$ was $26.75 \mathrm{~m} / \mathrm{s}$ (its square would be $715.48 \mathrm{~m}^{2} \mathrm{~s}^{-2}$ ). On the other hand, the $0-2 \mathrm{~km}$ pre-frontal windshear component (in the direction of storm propagation) was $16.23 \mathrm{~m} / \mathrm{s}$ (its square was $263.55 \mathrm{~m}^{2} \mathrm{~s}^{-2}$ ). This would suggest that even if the pre-storm deep-layer wind shear was large, the system was cold-pool dominated. However, we do not have any exact information about the influence of the rear-inflow-jet. We know that at 12:00 UTC, another meteorological station at Beograd Surčin (its WMO Id is 13272 and it is situated 12 $\mathrm{km}$ northwest of the sounding station) reported $13 \mathrm{~m} / \mathrm{s}$ northwesterly $\left(320^{\circ}\right)$ wind at $10 \mathrm{~m}$, already in the cold pool area. If we expect that the storm-relative wind component at the top of the cold pool was zero, this record would result in a 22.53 $\mathrm{m} / \mathrm{s}$ cold-pool shear component (its square yields $507.7 \mathrm{~m}^{2} \mathrm{~s}^{-2}$ ), which would substantially compensate the effect of the buoyant generation of vorticity in the cold pool. However, for more exact calculations we would need more observations or a non-hydrostatic numerical simulation.

In Table 6 one can find more results of $c$ versus $\Delta u$ comparison calculated for different heights of the cold pool. It shows that with increasing height of the cold pool also the vorticity balance defined by Eq.(2) becomes more satisfied, because the magnitude of the pre-storm shear increased significantly with height. Another issue is also the impact of the wind shear above the cold pool height (Coniglio et al., 2006), which can also balance the cold-pool vorticity generation. In the studied case, the 2-6 km pre-frontal wind shear component from Beograd sounding was $21.7 \mathrm{~m} / \mathrm{s}$ (its square was $472.23 \mathrm{~m}^{2} \mathrm{~s}^{-2}$ ), which would mean a significant contribution to the $0-2 \mathrm{~km}$ shear effect. 
Table 6. Comparison of the velocity of the net buoyant generation of vorticity and environmental wind shear derived from the Beograd Košutnjak (13275) September 17, 2017, 12:00 UTC sounding for several cold-pool heights.

\begin{tabular}{lllll}
\hline \hline cold-pool height (m AGL) & \multicolumn{2}{l}{$\begin{array}{l}\text { velocity of the net buoyant } \\
\text { generation of vorticity }\end{array}$} & \multicolumn{2}{l}{ environmental wind shear } \\
& $c(\mathrm{~m} / \mathrm{s})$ & $c^{2}\left(\mathrm{~m}^{2} \mathrm{~s}^{-2}\right)$ & $\Delta u(\mathrm{~m} / \mathrm{s})$ & $\Delta u^{2}\left(\mathrm{~m}^{2} \mathrm{~s}^{-2}\right)$ \\
\hline \hline 1500 & 25.38 & 644.37 & 11 & 121.1 \\
2000 & 26.75 & 715.48 & 16.23 & 263.55 \\
2500 & 26.87 & 721.78 & 21.46 & 460.7 \\
\hline
\end{tabular}

Finally, it is interesting to compare the September 17, 2017 pre-storm characteristics with environments of other derechos or with the published statistics (ED01) based on proximity soundings (Table 7). We can see that both sounding and model-derived MUCAPE values were significantly lower compared to other derechos, except of the cold-season one (Gatzen et al., 2011). On the other hand, concerning deep layer shear, the presented storm belonged to the high-shear events. Despite of the relatively dry environment, the DCAPE was still below the magnitude usually observed in derecho environments. On the other hand we could see that $40-50 \%$ average low level relative humidity occurred also by other derecho events. We also looked at the mean mixed-layer mixing ratio (not shown), where the 12:00 UTC Beograd sounding record $(5.76 \mathrm{~g} / \mathrm{kg})$ was the lowest. For other presented cases it was between 6 and 19 (average was $11 \mathrm{~g} / \mathrm{kg}$ ). The pre-storm DCP (both measured and modelcalculated) would also not indicate a usual environment of a long-lived storm, although we can see that for several other events it was also only about 1 or somewhat higher. The reason is above all the low CAPE and also moderate DCAPE with respect to other derecho environments. The presented cases in Table 7 of course show only a fraction of all possible situations, even in Europe. One should also take into account that the environment conditions change during the storm's lifetime, hence it is sometimes difficult to represent the entire storm evolution with a single sounding. A good example is the case of the May 8, 2009 derecho (Coniglio et al., 2011), which developed in a low-CAPE, highshear environment and propagated toward a very buoyant and moist airmass. 
Table 7. Comparison of some characteristics of the September 17, 2017 storm and its environment with some other known/published derecho events and the Evans and Doswell (2001) (ED01) statistics (showing the 25 and 75 percentiles). RH is relative humidity, NR is not relevant, WF is weak forcing, SF is strong forcing. The data were inferred from soundings in the proximity of the derecho events, data in parenthesis are from numerical analyses, cited in the publications.

\begin{tabular}{|c|c|c|c|c|c|c|c|c|}
\hline $\begin{array}{c}\text { Storm } \\
\text { date/statistics }\end{array}$ & $\begin{array}{c}\text { Region } \\
\text { (Sounding ID) }\end{array}$ & Forcing & $\begin{array}{c}\text { MUCAPE } \\
\text { or } \\
\text { SBCAPE* } \\
(\mathbf{J} / \mathbf{k g}) \\
\end{array}$ & $\begin{array}{l}\text { 0-6-km } \\
\text { shear } \\
(\mathrm{m} / \mathrm{s})\end{array}$ & $\begin{array}{l}\text { System } \\
\text { speed } \\
(\mathrm{m} / \mathrm{s})\end{array}$ & $\begin{array}{c}\text { DCAPE } \\
(\mathbf{J} / \mathbf{k g})\end{array}$ & $\begin{array}{c}\text { 0-3-km } \\
\text { RH } \\
\text { (\%) }\end{array}$ & DCP \\
\hline $\begin{array}{l}\text { Sep 17, } 2017 \\
\text { (this paper) }\end{array}$ & $\begin{array}{l}\text { Serbia/Romania } \\
\text { (13275) }\end{array}$ & WF & $\begin{array}{c}22.5 \\
(387.8)\end{array}$ & $\begin{array}{c}39.5 \\
(30.1)\end{array}$ & 26.5 & $\begin{array}{c}632.3 \\
(398.2)\end{array}$ & $\begin{array}{c}42.4 \\
(46.6)\end{array}$ & $\begin{array}{l}0.074 \\
(0.53)\end{array}$ \\
\hline ED01 25\% & NR & NR & 1686 & 11.8 & 15 & 817.3 & NR & NR \\
\hline ED01 75\% & NR & NR & 3947.5 & 20.0 & 20 & 1235.8 & NR & NR \\
\hline $\begin{array}{l}\text { July 5, } 2002 \\
\text { (Punkka et al., } \\
\text { 2006) }\end{array}$ & $\begin{array}{l}\text { Finland, } \\
\text { Russia, Estonia } \\
\text { (26063) }\end{array}$ & hybrid? & $\begin{array}{l}1476.3 \\
(1500)\end{array}$ & 14.9 & $20-25$ & 577.1 & 54.8 & 1.05 \\
\hline $\begin{array}{l}\text { July 10, 2002 } \\
\text { (Gatzen, 2004) }\end{array}$ & $\begin{array}{l}\text { Germany } \\
(10393)\end{array}$ & hybrid? & 1319.5 & 15.7 & $\sim 20$ & 744.2 & 58 & 0.98 \\
\hline $\begin{array}{l}\text { March 1, } 2008 \\
\text { (Gatzen et al., } \\
\text { 2011) }\end{array}$ & $\begin{array}{l}\text { Central Europe } \\
(11520)\end{array}$ & SF & 1.85 & $\begin{array}{l}40.4 \\
(50)\end{array}$ & 27.8 & 33.9 & 94.4 & $410^{-4}$ \\
\hline $\begin{array}{l}\text { June 25, } 2008 \\
\text { (Simon et al., } \\
\text { 2011) }\end{array}$ & $\begin{array}{l}\text { Central Europe } \\
\text { (11035) }\end{array}$ & WF & $\begin{array}{l}2085.1 \\
(2500)\end{array}$ & 24 & 17.5 & 767 & 54.1 & 2.5 \\
\hline $\begin{array}{l}\text { May 8, } 2009 \\
\text { (Coniglio et } \\
\text { al., 2011) }\end{array}$ & $\begin{array}{l}\text { Central USA: } \\
\text { Colorado, } \\
\text { Kansas, } \\
\text { Missouri } \\
\text { (72440 SGF) }\end{array}$ & WF & $\begin{array}{c}3154 \\
(300-500 \\
* *)\end{array}$ & $\begin{array}{c}27.3 \\
(27.5-35 \\
* *)\end{array}$ & $\sim 23.5$ & $\begin{array}{c}442.8 \\
(600 * *)\end{array}$ & 77.7 & 3.92 \\
\hline $\begin{array}{l}\text { July 20, } 2011 \\
\text { (Gospodinov et } \\
\text { al., 2015) }\end{array}$ & $\begin{array}{l}\text { Bulgaria } \\
\text { (15614) }\end{array}$ & hybrid & $\begin{array}{c}777.3 \\
(1424)\end{array}$ & 23.3 & $\sim 18$ & 793.8 & 42.5 & 1.27 \\
\hline $\begin{array}{l}\text { June } 30,2014 \\
\text { (Friedlein et al., } \\
\text { 2015) }\end{array}$ & $\begin{array}{l}\text { Midwest USA: } \\
\text { e.g., Nebraska, } \\
\text { Illinois, Iowa, } \\
\text { Michigan } \\
\text { (74560 ILX) }\end{array}$ & SF & $\begin{array}{c}4018.5 \\
(4000-6000)\end{array}$ & $\begin{array}{c}20.4 \\
(20-30)\end{array}$ & 27 & 378.6 & 51.8 & 3.22 \\
\hline
\end{tabular}

\footnotetext{
* All sounding records are MUCAPEs, certain referenced values are SBCAPEs (e.g., Gospodinov et al., 2015)
}

** refers to early development of the storm 


\section{Conclusions}

The case of the September 17, 2017 windstorm showed several characteristics, which were typical for a derecho event. High wind gusts and extensive damage occurred on the leading edge of a mesoscale convective system with trailing stratiform precipitation (TS-type, Parker and Johnson, 2000). The propagation speed of the system was high even in comparison with some climatological studies, where the median for derecho-producing MCSs was about $21 \mathrm{~m} / \mathrm{s}$ (Cohen et al., 2007). This was related to very strong winds and wind shear observed in the storm's environment. Despite of the strong mid- and upper tropospheric flow, the synoptic setting of the event was different from coldseason derechos, which are often related to a deep synoptic-scale cyclone and its cold front. The intensity of the studied storm was determined mainly by deep convection and to a less extent by large-scale pressure distribution. This can be demonstrated by the fact that the maximum wind gust forecast of the hydrostatic ECMWF model (including parameterization of convection) was $22 \mathrm{~m} / \mathrm{s}$ for the plain territory of Romania and $24 \mathrm{~m} / \mathrm{s}$ for the mountain regions, although the maximum observed gusts reached $40 \mathrm{~m} / \mathrm{s}$. The ECMWF model indicated a presence of weak mesosynoptic-scale upward vertical motions in mid- and upper tropospheric levels, which could be important for the development of convection and maintenance of the system. However, these vertical motions were not of frontal origin.

The convective system did not exhibit a large-scale, long-lived bow echo, which is often observed during derecho events and provides an important hint on presence of severe wind. On radar imagery, we could see only smaller-scale bow echoes over Romania or in the border region of Romania and Serbia. The system also showed a tendency to split into several segments and cells, maximum radar reflectivity of which was sometimes rather low, mainly on the southern and southeastern flank of the system (probably due to the inflow of drier environmental air). Splitting of system to individual cells or even chain of supercells is often expected in case of very high wind shear (Bluestein and Jain, 1985; Bluestein and Weisman, 2000). In our case, the compactness of the area of high wind gusts and associated damages indicate that these cells developed on the leading edge of one large, propagating cold pool. Due to high wind shear and possible presence of a rear-inflow jet, it is likely that the system was not cold pool-dominated and an equilibrium could develop between the cold poolgenerated horizontal vorticity and environmental shear. Also, because of low CAPE values in the pre-storm area, we did not observe that new cells would develop much ahead of the leading edge of the system, which is one mode of propagation of MCSs, due to gravity wave or bore generation (Lane and Moncrieff, 2015).

Concerning the pre-storm environment, low CAPE values, associated with low relative and specific humidity would be rather typical for a cold season 
derecho with strong forcing than for the described event. This feature poses a challenge for predictability of similar storms, since thunderstorms are usually not expected when the $0-3-\mathrm{km}$ average relative humidity drops below $50 \%$ (severe weather forecasters at OMSZ, personal communication). The pre-storm specific humidity was also quite low. For average non-severe thunderstorms in Europe, sounding-based climatology indicates low level mixing ratio exceeding $8 \mathrm{~g} / \mathrm{kg}$ in $75 \%$ of the cases. It is noteworthy that convective events accompanied by extremely severe wind gusts or weak tornadoes have lower 25 th percentile of occurrence (somewhat above $7 \mathrm{~g} / \mathrm{kg}$ ), and less than $10 \%$ of such cases can occur in very dry conditions, when the mixing ratio can be below $6 \mathrm{~g} / \mathrm{kg}$ (Taszarek et al., 2017). It is possible that the presence of unsaturated dry air close to the surface (and not only at mid-levels) could have influenced the intensity of the gusts via stronger evaporation of precipitation and intensification of downdrafts. As the convective system propagated, it carried also a more humid air from the west, which could be involved in the development of new convective cells. It is also important that at low levels, the storm-relative inflow was from moister regions on the northern-northeastern flank of the system. This could motivate to use products with depiction of storm-relative flow in the operational service. One should carefully identify possible sources of low-level humidity and admit that the environmental (pre-storm) relative and specific humidity in such cases can be lower than thresholds used for isolated thunderstorms.

Low CAPE values in the pre-storm region had also a consequence of low magnitude of "composite" parameters as DCP, which is, therefore, not useful as a derecho indicator in similar cases. Involvement of observed surface dew point and temperature in CAPE calculation showed that there could have been an increase of low-level humidity and buoyancy just ahead of the system, though this was present only at certain locations.

The investigated case is interesting from derecho climatology point of view, because it showed features typical for both warm- and cold season derechos, and some of its parameters (environmental wind shear, pre-storm moisture content) were rather unusual concerning available derecho statistics. It also occurred relatively late with respect to peak thunderstorm activity over the continent (including occurrence of intense MCSs), which is usually expected from May to August (Antonescu and Burcea, 2010). On the other hand, there was a strong southerly warm air advection and temperature conditions, which are atypical in mid-September, in this part of Europe.

Huge impact of the storm should motivate further study of similar longlived convective events, which are relatively rare and challenging from the forecasting point of view. A new perspective on the dynamics of the storm and its relation to the environment could be brought by forecasts of a high-resolution non-hydrostatic model. At the time of the event, such forecasts were not provided operationally for the entire area of the windstorm, because it would require a large domain and computational power. Outputs of such simulations 
could answer some important questions - for example, why the first convective systems occurring in the morning of September 17, 2017 did not cause substantial wind gusts, what was the reason for strong rightward deflection of the system during some periods of its existence, or how big was the influence of the rear-inflow-jet on the dynamics of the system. More detailed study and early detection of similar storms would also require higher density of observations and above all more information about the vertical wind profile from both prestorm and cold pool area.

Acknowledgements: The authors are grateful to many colleagues, who helped with processing of the input data and visualisation, above all to Rita Rétfalvi Hodossyné and Ildikó Szenyán (OMSZ). We would like to express our thank to Márk Rajnai (OMSZ) and Roland Steib (OMSZ) for many useful information and helpful discussions.

\section{References}

Antonescu, B. and Bell, A., 2015: Tornadoes in Romania. Mon. Weather Rev. 143, 689-701. https://doi.org/10.1175/MWR-D-14-00181.1

Antonescu, B. and Burcea, S., 2010: A cloud-to-ground lightning climatology for Romania. Mon. Weather Rev. 138, 579-591.

Bechtold, P. and Bidlot, J., 2009: Parameterization of convective gusts. ECMWF Newsletter 119, 15-18.

Bluestein, H.B. and Jain, M.H., 1985: Formation of mesoscale lines of precipitation: Severe squall lines in Oklahoma during the spring. J. Atmos. Sci. 42, 1711-1732.

Bluestein, H.B. and Weisman, M.L. 2000: The interaction of numerically simulated supercells initiated along lines. Mon. Weather Rev. 128, 3128-3149. https://doi.org/10.1175/1520-0493(2000)128<3128:TIONSS $>2.0$. CO;2

Browning, K. A., 1962: Cellular structure of convective storms. Meteor. Mag. 91, 341-350.

Bryan, G.H., Knievel, J.C., and Parker, M.D., 2006: A multimodel assessment of RKW theory's relevance to squall-line characteristics. Mon. Weather Rev. 134, 2772-2792.

Bunkers, M.J., 2009: Comments on "Observational analysis of the predictability of mesoscale convective systems." Wea. Forecasting 24, 351-355. https://doi.org/10.1175/2008WAF2222129.1

Bunkers, M.J., Klimowski, B.A., Zeitler, J.W., Thompson, R.L., and Weisman, M.L., 2000: Predicting supercell motion using a new hodograph technique. Wea. Forecasting 15, 61-79. https://doi.org/10.1175/1520-0434(2000)015<0061:PSMUAN>2.0.CO;2

Bunkers, M.J., Hjelmfelt, M.R., and Smith, Jr., P.L., 2006: An observational examination of long-lived supercells. Part I: Characteristics, evolution, and demise. Wea. Forecasting 21, 673-688. https://doi.org/10.1175/WAF949.1

Celiński-Mystaw D. and Matuszko D., 2014: An analysis of the selected cases of derecho in Poland, Atmos. Res.149, 263-281. https://doi.org/10.1016/j.atmosres.2014.06.016

Cohen, A.E., Coniglio, M.C., Corfidi, S.F., and Corfidi, S.J., 2007: Discrimination of mesoscale convective system environments using sounding observations. Wea. Forecasting 22, 1045-1062. https://doi.org/10.1175/WAF1040.1

Colby, F. P., 1984: Convective Inhibition as a Predictor of Convection during AVE-SESAME II. Mon. Weather Rev. 112, 2239-2252. https://doi.org/10.1175/1520-0493(1984)112<2239:CIAAPO >2.0.CO;2

Coniglio M.C., Stensrud D.J., and Richman M.B., 2004: An observational study of derecho-producing convective systems, Wea. Forecasting 19, 320-337.

https://doi.org/10.1175/1520-0434(2004)019<0320:AOSODC $>2.0 . C O ; 2$ 
Coniglio, M.C., S. F. Corfidi, and Kain, J. S., 2011: Environment and early evolution of the 8 May 2009 derecho-producing convective system. Mon. Weather Rev.139,1083-1102. https://doi.org/10.1175/2010MWR3413.1

Coniglio, M. C., Corfidi, S.F., and Kain, J.S., 2012: Views on applying RKW theory: An illustration using the 8 May 2009 derecho-producing convective system. Mon. Weather Rev. 140, 10231043. https://doi.org/10.1175/MWR-D-11-00026.1

Coniglio, M.C., Stensrud, D.J., and Wicker, L.J., 2006: Effects of upper-level shear on the structure and maintenance of strong quasi-linear mesoscale convective systems. J. Atmos. Sci. 63, 12311252. https://doi.org/10.1175/JAS3681.1

Corfidi, S.F., 2003: Cold pools and MCS propagation: Forecasting the motion of downwinddeveloping MCSs. Wea. Forecasting 18, 265-285. https://doi.org/10.1175/1520-0434(2003)018<0997:CPAMPF $>2.0 . C O ; 2$

Corfidi, S.F., Cohen, A.E., Coniglio, M.C., and Mead, C.M., 2016: A proposed revision to the definition of "Derecho". Bull. Amer. Meteor. Soc. 96, 935-949. https://doi.org/10.1175/BAMS-D-14-00254.1

Corfidi, S.F., Merritt, J.H., and Fritsch, J.M, 1996: Predicting the movement of mesoscale convective complexes. Wea. Forecasting 11, 41-46. https://doi.org/10.1175/1520-0434(1996)011<0041:PTMOMC $>2.0 . C O ; 2$

Craven, J.P., Jewell, R.P., and Brooks, H.E., 2002: Comparison between Observed Convective CloudBase Heights and Lifting Condensation Level for Two Different Lifted Parcels, Wea. Forecasting 17, 885-890. https://doi.org/10.1175/1520-0434(2002)017<0885:CBOCCB $>2.0 . C O ; 2$

Csirmaz, K., 2013: A konvektív elörejelzéshez használt diagnosztikus paraméterek és indexek számolásának dokumentációja, Technical documentation, OMSZ, 27 p. (in Hungarian)

Davies, J.M., 2004: Estimations of CIN and LFC Associated with Tornadic and Nontornadic Supercells, Wea. Forecasting 19, 714-726. https://doi.org/10.1175/1520-0434(2004)019<0714:EOCALA >2.0.CO;2

Davies-Jones, R., Burgess, D., and Foster, M., 1990: Test of helicity as a tornado forecast parameter. Preprints, 16th Conf. on Severe Local Storms, Kananaskis Park, AB, Canada: Amer. Meteor. Soc., 588-592.

Doswell C.A., III and Rasmussen,E.N., 1994: The Effect of Neglecting the Virtual Temperature Correction on CAPE Calculations. Wea. Forecasting 9, 625-629. https://doi.org/10.1175/1520-0434(1994)009<0625:TEONTV>2.0.CO;2

Doswell, C.A., III and Schultz, D.M., 2006: On the use of indices and parameters in forecasting severe storms. Electron. J. Severe Storms Meteor. 1, 1-22.

Emanuel, K.A., 1994: Atmospheric Convection. Oxford University Press. 580 pp.

EUMETSAT, 2014: IASI L2 PPFv6: Validation Report. Internal report, EUMETSAT, $\mathrm{EUM} / \mathrm{TSS} / \mathrm{REP} / 14 / 776,290 \mathrm{pp}$.

http://www.eumetsat.int/website/wcm/idc/idcplg?IdcService=GET_FILE\&dDocName=PDF_D

MT_776443\&RevisionSelectionMethod=LatestReleased\&Rendition=Web

European Severe Weather Database, 2019: Website of the European Severe Weather Database. Accessed 16 April 2019, http://www.eswd.eu/

Evans J.S., and Doswell III C.A., 2001: Examination of derecho environments proximity soundings. Wea. Forecasting 16, 329-342. https://doi.org/10.1175/1520-0434(2001)016<0329:EODEUP>2.0.CO;2

Friedlein, M.T., Castro, R., Lenning, E., Lyza, W.A., Knupp, K.R., 2015: Evolution of the 30 June 2014 Double Derecho Event in Northern Illinois and Northwest Indiana. Proceedings, 27th Conference on Weather Analysis and Forecasting/23rd Conference on Numerical Weather Prediction, Chicago, Illinois., 9 pp.

Fujita, T.T., D.L. Bradbury, and C.F. Thullenar, 1970: Palm Sunday tornadoes of April 11, 1965. Mon. Wea. Rev., 98, 29-69.

https://doi.org/10.1175/1520-0493(1970)098<0029:PSTOA $>2.3 . C O ; 2$

Fujita, T.T., 1978: Manual of downburst identification for project NIMROD. Satellite and Mesometeorology Res. Pap. No. 156, University of Chicago, Dept. of Geophysical Sciences, pp. 104. 
Galway, J.G., 1956. The lifted index as a predictor of latent instability. Bull. Am. Meteorol. Soc. 37, 528-529. https://doi.org/10.1175/1520-0477-37.10.528

Gatzen, C., 2004: A derecho in Europe: Berlin, 10 July 2002. Wea. Forecasting 19, 639-645. https://doi.org/10.1175/1520-0434(2004)019<0639:ADIEBJ >2.0.CO;2

Gatzen, C., Fink, A., Joaquim, P., Schultz, D., 2015. Analysis of a 18-year climatology of German derechos. Presentation, 8th European Conference on Severe Storms, 14-18 September 2015, Wiener Neustadt, Austria.

Gatzen, C., Púčik, T., and Rýva, D. , 2011: Two cold-season derechoes in Europe. Atmos. Res. 100, 740-748. https://doi.org/10.1016/j.atmosres.2010.11.015

Gilmore, M.S. and Wicker, L.J., 1998. The influence of midtropospheric dryness on supercell morphology and evolution. Mon. Weather Rev. 126, 943-958. https://doi.org/10.1175/1520-0493(1998)126<0943:TIOMDO >2.0.CO;2

Gospodinov, I., Dimitrova, Ts., Bocheva, L., Simeonov, P., Dimitrov, R., 2015: Derecho-like event in Bulgaria on 20 July 2011. Atmos. Res. 158-159, 254-273.

https://doi.org/10.1016/j.atmosres.2014.05.009

Johns, R. H. and Hirt, W. D., 1987: Derechos: widespread convectively induced windstorms. Wea. Forecasting 2, 32-49. https://doi.org/10.1175/1520-0434(1987)002<0032:DWCIW>2.0.CO;2

Lagerquist, R., McGovern A., and Smith, T., 2017: Machine learning for real-time prediction of damaging straight-line convective wind. Wea. Forecasting 32, 2175-2193. https://doi.org/10.1175/WAF-D-17-0038.1

Lane, T. P., and Moncrieff, M. W., 2015: Long-lived mesoscale systems in a low-convective inhibition environment. Part I: Upshear propagation. J. Atmos. Sci. 72, 4297-4318. https://doi.org/10.1175/JAS-D-15-0073.1

Lemon, L. R., Stan-Sion, A., Soci, C., and Cordoneanu, E., 2003: A strong, long-track, Romanian tornado. Atmos. Res. 67-68, 391-416. https://doi.org/10.1016/S0169-8095(03)00063-2

Lompar, M., Curic, M., and Romanic, D., 2017: Simulation of a severe convective storm using a numerical model with explicitly incorporated aerosols. Atmos. Res. 194, 164-177. https://doi.org/10.1016/j.atmosres.2017.04.037

Lopez J. M., 2007: A mediterranean derecho: Katalonia (Spain), 17th August 2003, Atmos.Res. 83, 272-283. https://doi.org/10.1016/j.atmosres.2005.08.008

Mahoney, K.M., Lackmann, G.M., and Parker, M.D., 2009: The role of momentum transport in the motion of a quasi-idealized mesoscale convective system. Mon. Weather Rev. 137, 3316-3338. https://doi.org/10.1175/2009MWR2895.1

Moller, A.R., Doswell III, C.A., Foster, M.P., and Woodall, G.R..1994: The operational recognition of supercell thunderstorm environments and storm structures. Wea. Forecasting 9, 327-347. https://doi.org/10.1175/1520-0434(1994)009<0327:TOROST >2.0.CO;2

Parker, M.D., and Johnson, R.H., 2000: Organizational modes of midlatitude mesoscale convective systems. Mon. Weather Rev. 128, 3413-3436. https://doi.org/10.1175/1520-0493(2001)129<3413:OMOMMC >2.0.CO;2

Pavlović-Berdon, N., Zarić, M., and Stanković, A., 2013: The occurrence of a tornado in Serbia on 31 march 2013. Journal of the Geographical Institute Jovan Cvijic, SASA. 63. 321-334. https://doi.org/10.2298/IJGI1303321P

Persson, A., 2011: User guide to ECMWF forecast products. Meteorol. Bull. M3.2, ECMWF.

Petersen, W. A., Rutledge, S. A., and Orville, R. E., 1996: Cloud-to-Ground Lightning Observations from TOGA COARE: Selected Results and Lightning Location Algorithms, Mon. Weather Rev. 124, 602-620. https://doi.org/10.1175/1520-0493(1996)124<0602:CTGLOF $>2.0 . C O ; 2$

Púčik, T., Francová, M., Rýva, D. Kolár̆, M., and Ronge, L., 2011: Forecasting challenges during the severe weather outbreak in Central Europe on 25 June 2008. Atmos. Res. 100, 680-704. https://doi.org/10.1016/j.atmosres.2010.11.014

Punkka A-J., Teittinen J., and Johns R.H., 2006: Synoptic and mesoscale analysis of a high-latitude derecho-severe thunderstorm outbreak in Finland on 5 July 2002, Wea. Forecasting 21, 752 763. https://doi.org/10.1175/WAF953.1 
Rabrenović, M., 2015: Analysis of an outbreak of extremely severe weather followed by tornado in Serbia. Presentation, 8th European Conference on Severe Storms, 14-18 September 2015, Wiener Neustadt, Austria.

Rabrenović, M. and Gatzen, C., 2017: Analysis of severe convective wind gusts in Serbia. Presentation, 9th European Conference on Severe Storms, ECSS2017-189, 18-22 September 2017, Pula, Croatia.

Rajnai, M., and Vörös, M., 2010: Recent Developments in HAWK-3. Presentation, 21st Workshop of the European Working Group on Operational meteorological Workstations, EGOWS, ECMWF, Reading, UK, 1st June 2010.

Rasmussen, E. and Blanchard, D., 1998. A baseline climatology of soundingderived supercell and tornado forecast parameters. Wea. Forecasting 13, 1148-1164. https://doi.org/10.1175/1520-0434(1998)013<1148:ABCOSD>2.0.CO;2

Roman, J. A., Knuteson, R., August, T., Hultberg, T., Ackerman, S.A., and Revercomb, H., 2016: A global assessment of NASA AIRS v6 and EUMETSAT IASI v6 precipitable water vapor using ground-based GPS SuomiNet stations. J. Geophys. Res. Atmos. 121, 8925-8948. https://doi.org/10.1002/2016JD024806

Rotunno, R.J., Klemp, J. B., and Weisman, M. L., 1988: A theory for strong, long-lived squall lines. J. Atmos. Sci. 45, 463-485. https://doi.org/10.1175/1520-0469(1988)045<0463:ATFSLL $>2.0 . C O ; 2$

Simon A., Kañák J., Sokol A., Putsay M., Uhrínová L., Csirmaz K., Okon L', and Habrovský R., 2011: Case study of a severe windstorm over Slovakia and Hungary on 25 June 2008, Atmos. Res. 100, 705-739. https://doi.org/10.1016/j.atmosres.2010.12.012

Storm Prediction Center, 2019: Derecho composite parameter (DCP). Website. Accessed 16 April 2019, http://www.spc.noaa.gov/exper/mesoanalysis/help/help_dcp.html

Taszarek, M., Brooks, H.E., and Czernecki, B., 2017: Sounding-derived parameters associated with convective hazards in Europe. Mon. Weather Rev. 145, 1511-1528. https://doi.org/10.1175/MWR-D-16-0384.1

Taszarek, M., Pilguj, N., Orlikowski, J., Surowiecki, A., Walczakiewicz, Sz., Pilorz, W., Piasecki, K., Pajurek, E., and Pótrolniczak, M., 2019: Derecho evolving from a mesocyclone - a study of 11 August 2017 severe weather outbreak in Poland: event analysis and high-resolution simulation, Mon. Weather Rev.147, 2283-2306. https://doi.org/10.1175/MWR-D-18-0330.1

Thompson, R.L., Edwards, R., Hart, J.A., Elmore, K.L., and Markowski, P., 2003: Close Proximity Soundings within Supercell Environments Obtained from the Rapid Update Cycle, Wea. Forecasting 18, 1243-1261. https://doi.org/10.1175/1520-0434(2003)018<1243:CPSWSE $>2.0 . C O ; 2$

University of Wyoming, 2019: Upperair Air Data, Soundings, Website. Accessed 16 April 2019, http://www.weather.uwyo.edu/upperair/sounding.html

Weisman, M. L. and Trapp, R. J., 2003: Low-level mesovortices within squall lines and bow echoes. Part I: Overview and dependence on environmental shear. Mon. Weather Rev. 131, 2779-2803. https://doi.org/10.1175/1520-0493(2003)131<2779:LMWSLA>2.0.CO;2

Weisman, M.L., 1992: The role of convectively generated rear-inflow jets in the evolution of longlived mesoconvective systems. J. Atmos. Sci. 49, 1826-1847. https://doi.org/10.1175/1520-0469(1992)049<1826:TROCGR>2.0.CO;2

WordClimate, 2019: WorldClimate. Website, Accessed 16 April 2019, http://www.worldclimate.com/ Youtube, 2019: Nevreme u Hrtkovcima 1, 2017, Website, Accessed 16 April 2019, https://www.youtube.com/watch?v=naJ8kaSuNu0, Nevreme (Tornado)-Srbija 17.09.2017 (Okolina Zrenjanina-Tomasevac), Website, Accessed 16April 2019, https://www.youtube.com/watch?v=utP-TPNRbDQ, 